\title{
Health Risk Assessment for Area 514 RCRA Closure
}

Gretchen Gallegos

Linda C. Hall

JUNE 2006

U.S. Department of Energy

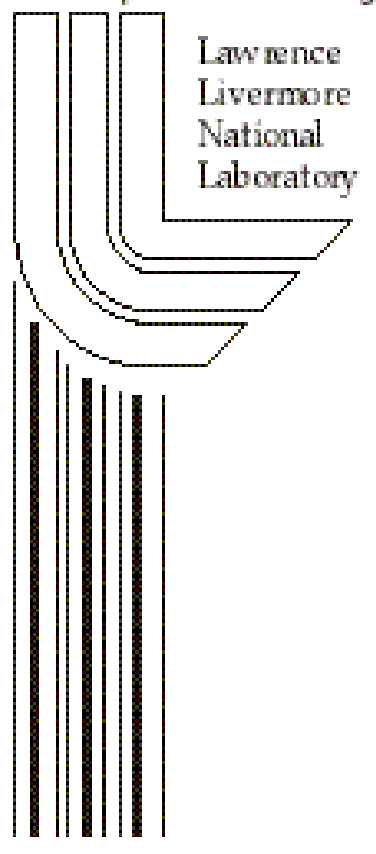


This work was performed under the auspices of the U. S. Department of Energy by the University of California, Lawrence Livermore National Laboratory under Contract No. W7405-Eng-48. 


\section{Table of Contents}

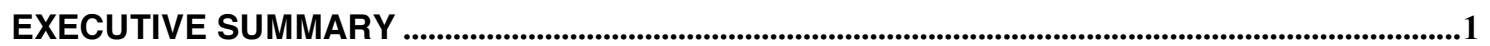

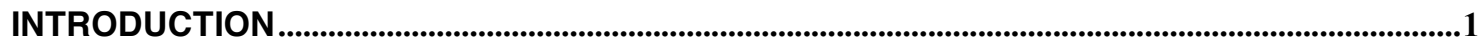

CONSTITUENTS OF POTENTIAL CONCERN …...............................................................................2

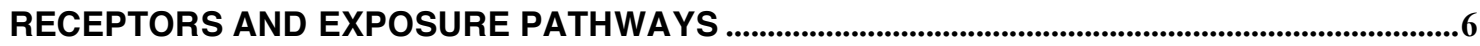

UNCERTAINTIES AND CONSERVATISMS ……................................................................................12

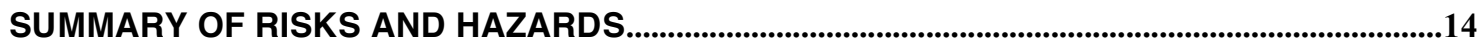

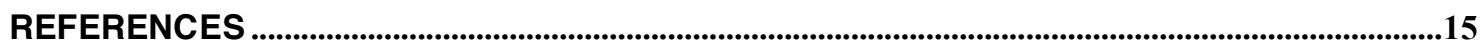

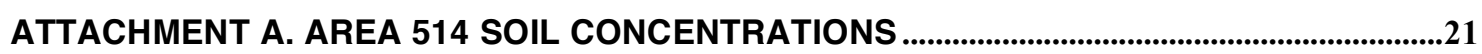

ATTACHMENT B. AREA 514 RISK AND HAZARD CALCULATIONS ............................................23 


\section{Executive Summary}

Lawrence Livermore National Laboratory (LLNL) is a U.S. Department of Energy research and development institution for science and technology applied to national security. The specific area that is the subject of this document, Area 514, was the location of active LLNL waste treatment facilities until November 2003, and the operations there were authorized under interim status. The site is being closed pursuant to the requirements of the Resource Conservation Recovery Act. The DTSC-approved Closure Plan for Area 514 Treatment and Storage Facility, LLNL 2004, states clean closure concentrations for certain organic compounds, metals and metalloids. If all soil samples contained measured concentrations less than these levels, it was agreed that the site would meet the requirements for clean closure. However, if the samples had measured concentrations greater than the clean closure levels, a more detailed risk assessment could be prepared to evaluate the potential effects of the actual measured levels.

Soil samples collected from 33 locations in Area 514 were analyzed for 37 constituents of potential concern, as identified by the Closure Plan. Many of these compounds and elements were not detected. However, 10 metals or metalloids were present at levels above the clean closure requirements, and 19 organic compounds were identified as contaminants of potential concern. Following the guidance in the Closure Plan, a health risk assessment is presented in this document to demonstrate the low level of potential health effects from the remaining constituents and to support clean closure of the site. Three types of hypothetical receptors were identified: an intrusive construction worker conducting trenching in the area, a bystander worker in a nearby building, and a future resident. Of the worker receptors, the intrusive construction worker was found to have the greater overall chronic exposure, with a theoretical calculated carcinogenic risk of $4 \times 10^{-8}$, a chronic hazard index of $8 \times 10^{-3}$, and an acute hazard index of $9 \times 10^{-1}$. The estimated incremental cancer risk for the residential receptor, $1 \times 10^{-6}$, was calculated by adjusting contaminant concentrations to account for background levels of metals at the Livermore LLNL site. When no adjustments for background concentrations are made, the estimated incremental cancer risk is $3 \times 10^{-6}$. The chronic hazard index for the residential receptor, $2 \times 10^{-1}$, was developed without accounting for background concentrations of metals. These values are all below levels associated with health concerns, and support the conclusion that further cleanup of the area is not necessary.

\section{Introduction}

Lawrence Livermore National Laboratory (LLNL) is a U.S. Department of Energy research and development institution for science and technology applied to national security. Waste storage and treatment activities for LLNL were conducted in Building 514 and associated buildings and outside areas from the 1950s (Dreicer, 1985) until November 2003. As of 2003, LLNL had built and permitted its Decontamination Waste Treatment Facility (DWTF), and the waste treatment facilities at Building 514 were no longer necessary. Area 514, the small area that is the subject of this human health risk assessment, is the area that remains after the removal of the buildings and treatment facilities. The site is being closed pursuant to the requirements of the Resource Conservation Recovery Act.

Currently, all the structures and equipment associated with Area 514 have been removed, with the exception of a remaining covered cement pad in the northeast corner. The site is pictured 
in Figure 1. The plan for the site is to cover it with asphalt and incorporate it into a parking area. Figure 2 shows the location of Area 514 within the LLNL Livermore site.

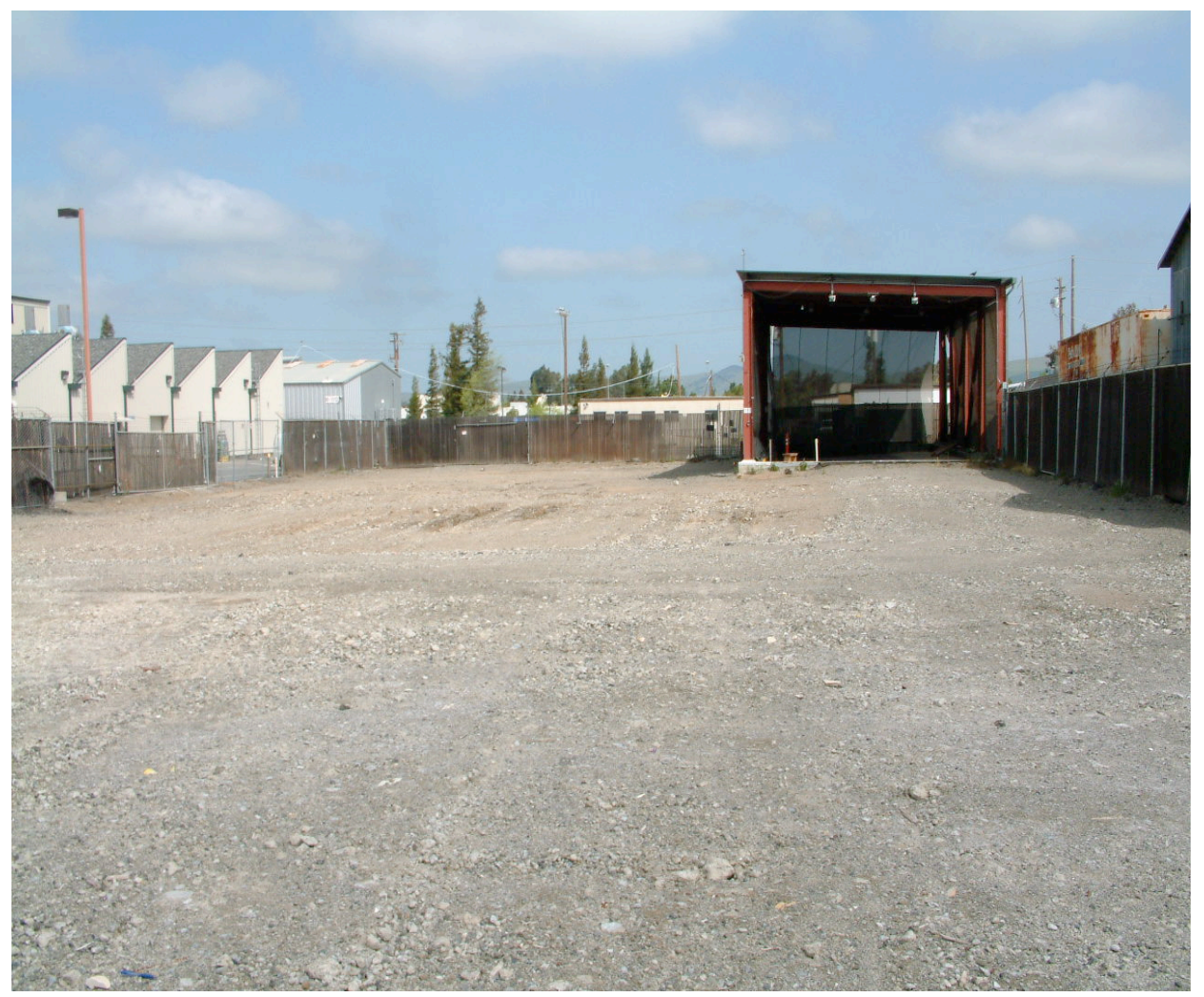

Figure 1. Area 514, view looking north, remaining covered concrete pad shown in the northeast corner. (Photo taken April 2005).

\section{Constituents of Potential Concern}

The DTSC-approved Closure Plan for Area 514 Treatment and Storage Facility, LLNL 2004 (Abri, 2004) includes clean closure concentrations for certain organic compounds and metals. If all measured values of these constituents in soil were less than these levels, it was agreed that the site would meet the requirements for clean closure.

The clean closure concentrations for metals and metalloids accepted by the DTSC for clean closure represent an upper limit estimate of naturally occurring levels at the Livermore site. LLNL's Livermore site is a highly developed site, and many construction activities occur annually that generate excess soil. The clean closure concentrations (screening limits) were initially developed to support the beneficial reuse of soils that are generated by construction or maintenance so that soils would not be unnecessarily sent to land fills (Folks, 1997).

The Livermore site consists primarily of unconsolidated materials, and the locations chosen for developing local values are representative of the entire site; areas of known contamination were expressly excluded from consideration in the development of these levels. The measurement data sets, which were based on more than 150 samples, were mathematically transformed, when possible, to achieve the best possible fit to the normal distribution (Folks, 
1997). A $99.5 \%$ prediction limit was selected to define the local background screening values. This $99.5 \%$ level was chosen to minimize the occurrence of false positive determinations; the intended use of the screening level was the comparison of a single or a few samples to it to determine whether or not further investigation was necessary. This method is consistent with DTSC guidance (DTSC, 1997), and was accepted by DTSC in the Closure Plan. A further discussion of the development of these levels is presented in Attachment A. Within the context of this human health risk assessment, an inorganic constituent of potential concern (COPC) determined to be present at levels below the clean closure concentrations was excluded from further analysis. Specifically, metals/metalloids were removed from the list of COPCs if the maximum concentration was less than the clean closure (background) value, but were retained if the maximum detected concentration was above the 95\% UCL concentration. Although clean closure concentrations were also developed for organic compounds (see Table 1), all of these materials were retained as COPCs, although four were eventually excluded from the list of compounds carried through the risk assessment because they were detected in field blank samples or were infrequently detected (see discussion below).

The COPCs for the Livermore site and their associated clean closure concentrations are presented in Table 1.

Table 1. Clean closure concentrations for constituents in soil.

\begin{tabular}{|l|c|l|c|}
\hline Constituent & $\begin{array}{c}\text { Clean Closure } \\
\text { Concentration } \\
(\mathrm{mg} / \mathrm{kg})\end{array}$ & Constituent & $\begin{array}{c}\text { Clean Closure } \\
\text { Concentration } \\
(\mathrm{mg} / \mathrm{kg})\end{array}$ \\
\hline Organic compounds & 0.24 & Metals and metalloids & \\
Acetone & 0.044 & Antimony & 1.12 \\
Benzene & 0.012 & Arsenic & 8.51 \\
Carbon tetrachloride & 0.098 & Barium & 308 \\
Chloroform & 0.29 & Cadmium & 0.62 \\
Chloromethane & 100 & Chromium & 1.59 \\
Cyanide & 0.00065 & Chromium VI & 72.4 \\
Endrin & 0.0045 & Cobalt & $\mathrm{NA}$ \\
Ethylene dichloride & 0.014 & Copper & 14.6 \\
Heptachlor & 3.9 & Lead & 62.5 \\
Methyl ethyl ketone & 0.077 & Mercury & 43.7 \\
Methylene chloride & 0.22 & Molybdenum & 0.14 \\
PCB & 4.4 & Nickel & 2.5 \\
Pentachlorophenol & 0.088 & Selenium & 82.8 \\
Tetrachloroethylene & 2.9 & Silver & 0.4 \\
Toluene & 0.033 & Thallium & 2.5 \\
1,1,2-Trichloroethane & 0.26 & Vanadium & 0.5 \\
Trichloroethylene & 0.566 & Zinc & 65.2 \\
Trichlorofluoromethane & 1.5 & & 75.3 \\
Xylene & & \\
\hline
\end{tabular}

${ }^{1}$ Any detection of chromium $\mathrm{VI}$ is considered to be above the clean closure concentration.

To characterize Area 514 for COPCs, soil samples were collected at 33 locations throughout the Area at a series of depths, including the surface, 2 feet, 5 feet, 10 feet, 15 feet, and 20 feet deep. Following guidance in the Closure Plan, samples were analyzed sequentially from the surface to the 20-foot depth; when the results for two consecutive depths were less than the 
clean closure levels, no further analyses were performed. The purpose of sampling at depth was to determine the vertical extent of surface contamination. (The depth to groundwater is approximately 100 feet at this location. The minimal potential effects on groundwater are discussed in Mansoor et al., 2006.) These samples were analyzed for the COPCs. Most of these constituents were well below the concentrations listed in Table 1. However, thirteen organic constituents and ten metals were found to be present in one or more samples in concentrations greater than the clean closure levels listed in Table 1, thus triggering a more thorough analysis of the effects of the COPCs measured at Area 514.

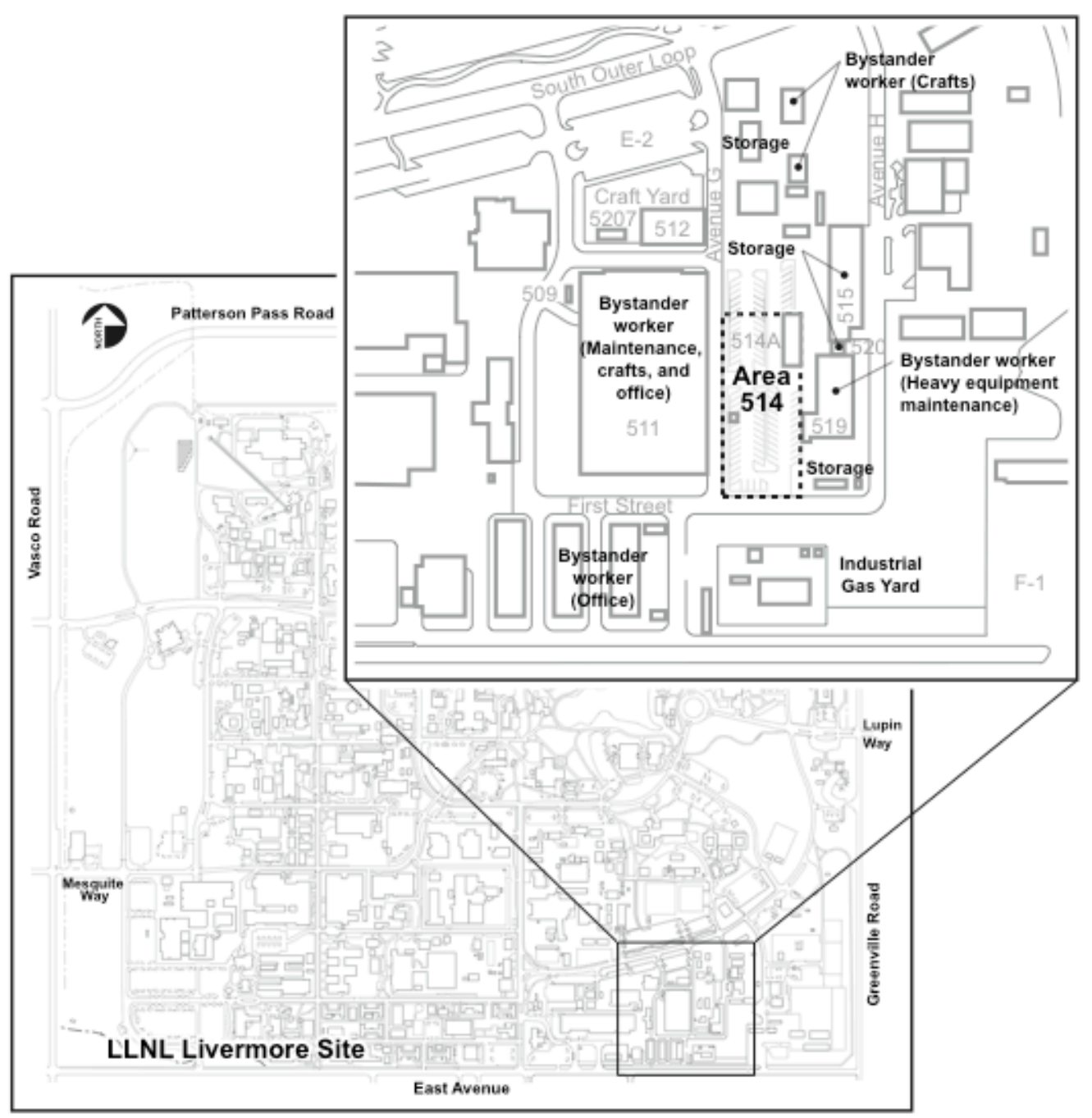

Figure 2. LLNL Livermore site, illustrating Area 514 (outlined with dashed line), nearby facilities, and potential on site bystander receptors.

Measured levels for eight metals and metalloids were less than the clean closure/local background values at all 33 sample locations. These materials and the highest detected values are as follows: antimony, $1 \mathrm{mg} / \mathrm{kg}$; arsenic, $5.7 \mathrm{mg} / \mathrm{kg}$; barium, $276 \mathrm{mg} / \mathrm{kg}$; cadmium, 0.56 $\mathrm{mg} / \mathrm{kg}$; lead, $15.6 \mathrm{mg} / \mathrm{kg}$; molybdenum, $1.6 \mathrm{mg} / \mathrm{kg}$; thallium, $0.5 \mathrm{mg} / \mathrm{kg}$; and selenium, which had no measured value greater than the detection limit. With four exceptions, all of the organic chemicals were included as constituents of concern. Acetone and methylene chloride 
were excluded from consideration because they were present in field blanks. Consistent with guidance (U.S. EPA, 1989), trichlorofluoromethane and cyanide were also omitted as COPCs because of their low frequency of detection $(\leq 2 \%)$ and low concentration.

Trichlorofluoromethane was detected a single time out of 120 samples, and was detected at a relatively low concentration $(0.004 \mathrm{mg} / \mathrm{kg})$. Cyanide was detected twice out of 98 samples, at 0.29 and $0.65 \mathrm{mg} / \mathrm{kg}$. (Although carbon tetrachloride was also detected a single time, we opted to retain it as a COPC due to its classification by the US EPA as a Group B2 or Probable Human Carcinogen; it's inclusion as a COPC is health-conservative.)

The presence of more uncommon constituents of concern, such as silver, cobalt, and organic materials at Area 514 was not unexpected. Building 514 was the location where waste was handled for LLNL from the 1950s until 2003, so the presence of solvents, PCBs, and other materials not usually found in the environment is, nonetheless, within the scope of operations of the facility. For example, one of the operations at Building 514 was a silver recovery unit, where silver was extracted from photograph-developing materials.

Following the identification of the materials to be evaluated in the risk assessment, the next step was to calculate the exposure concentrations for each constituent. DTSC and U.S. EPA (2002) guidance was followed for determining the exposure concentrations. A large number of the analytical results were values less than the detection limits (i.e., the level below the analytical laboratory can quantify the material with certainty). For values less than the detection limit, the analytical laboratory supplied estimated values of the quantity present; the estimated values were handled in the same manner as detections. In addition, in accordance with DTSC guidance, the exposure concentrations were based on the 95\% UCL on the mean of the measured concentrations at soil depths up to 10 feet (for those samples that were analyzed at depths greater than 2 feet). The data for three of the constituents (chromium, nickel, and vanadium) were lognormally distributed and the 95\% UCL was calculated according to the Land Method (U.S. EPA, 2002, Exhibit 3). Data for the remaining constituents did not fit any distribution, and the 95\% UCL on the mean was calculated using the adjusted Central Limit Theorem (U.S. EPA, 2002, Exhibit 8). The constituents of concern and the 95\% UCL values are listed in Table 2; see Attachment B for the measured values for individual samples. The equations used in calculating the $95 \%$ UCLs are reproduced below.

$$
\begin{aligned}
& \text { Land Method: } \\
& U C L_{95}=\exp \left(\overline{\ln X}+s_{\ln x}^{2} / 2+H_{95} s_{\ln x} / \sqrt{n-1}\right)
\end{aligned}
$$

Adjusted Central Limit Theorem Method:

$$
U C L_{95}=\bar{x}+\left(1.645+\frac{\beta}{6 \sqrt{n}}(5.41)\right) s / \sqrt{n},
$$

where $\beta$ is the calculated skewness of the data,

$$
\beta=\frac{n}{(n-1)(n-2)} \sum_{i=1}^{n}\left(\frac{x_{i}-\bar{x}}{S}\right)^{3} \text {. }
$$

All data used in calculating the 95\% UCLs are presented in Attachment A to this document. 
Following DTSC guidance (1996), we estimated incremental excess cancer risk for carcinogenic metals by either (1) subtracting the site background concentration from the $95 \%$ UCL when the UCL was greater than background (cobalt); or (2) omitting the metal from cancer risk calculations if the background concentration exceeded the 95\% UCL (beryllium and nickel). Calculations of non-cancer hazard were based on 95\% UCL concentrations for all constituents of concern (no adjustment was made for background levels).

Table 2. Concentrations of constituents of potential concern used to calculate exposure.

\begin{tabular}{|l|c|l|c|}
\hline Constituent & $\begin{array}{c}\text { Exposure } \\
\text { Concentration } \\
(\mathrm{mg} / \mathrm{kg})^{\mathrm{a}}\end{array}$ & Constituent & $\begin{array}{c}\text { Exposure } \\
\text { Concentration } \\
(\mathrm{mg} / \mathrm{kg})^{\mathrm{a}}\end{array}$ \\
\hline $\begin{array}{c}\text { Organic compounds } \\
\text { Benzene }\end{array}$ & 0.00023 & $\begin{array}{c}\text { Metals and metalloids } \\
\text { Beryllium }\end{array}$ & $0.36^{\mathrm{b}}$ \\
Bis-2-ethylhexyl phthlate & 0.082 & Chromium & 34.5 \\
Bromomethane & 0.001 & Chromium VI & 0.33 \\
Carbon tetrachloride & 0.00015 & Cobalt & $39.5^{\mathrm{c}}$ \\
Chloroform & 0.00016 & Copper & 27.5 \\
Chloromethane & 0.00027 & Mercury & 0.11 \\
Dibutyl phthlate & 0.088 & Nickel & $48.3^{\mathrm{b}}$ \\
Methylene chloride & 0.005 & Silver & 1.2 \\
Methyl ethyl ketone & 0.0047 & Vanadium & 34.5 \\
Methyl isobutyl ketone & 0.0065 & Zinc & 64.2 \\
PCBs & 0.058 & & \\
Arochlor 1242 & 0.019 & & \\
Arochlor 1256 & 0.049 & & \\
Arochlor 1260 & & & \\
Petroleum hydrocarbons & 142 & & \\
as diesel & 0.010 & & \\
Tetrachloroethylene & 0.00081 & & \\
Toluene & 0.0007 & & \\
Trichloroethane 1,1,1- & 0.037 & & \\
Trichloroethylene & 0.0021 & & \\
Xylenes & & \\
\hline
\end{tabular}

${ }^{a}$ Exposure concentrations are the $95 \%$ UCL unless noted.

${ }^{\mathrm{b}}$ Background concentration exceeds $95 \% \mathrm{UCL}$, so constituent was not included in calculations of cancer risk.

${ }^{c}$ Background concentration subtracted from this value to yield a concentration of $24.9 \mathrm{mg} / \mathrm{kg}$ for cancer risk calculations.

\section{Receptors and Exposure Pathways}

Area 514 is small and encompasses approximately 25,000 square feet. It is in the area of the LLNL Livermore site where many plant maintenance activities and crafts shops, such as carpentry, welding, and heavy equipment maintenance, are currently located. The intended use of the area is a parking lot supporting plant maintenance personnel. The receptors of concern are the bystander workers, i.e., those who have a work area or office near Area 514, but do not work directly in the area, and the intrusive construction workers, i.e., those who may work directly in the area, doing trenching or other construction work on an intermittent basis. Figure 2 shows the location of existing buildings and potential receptors near the area. In addition, a hypothetical future residential receptor was evaluated based on the possibility that a change in property ownership could make the site available in the future for residential occupancy. 
For the bystander worker, the relevant exposure pathway is inhalation of particles or volatile materials released from Area 514. The construction worker's potential exposure routes include inhalation of the constituents of concern, dermal exposure, and incidental ingestion of contaminated soil in the area. The construction worker's exposure is to soils that extend from the surface to approximately 5 or 6 feet deep; the work to be accomplished is the placement of substructures for storm water drainage. Drinking water was not evaluated as a pathway to the worker because ground water is not a source of drinking water for LLNL Livermore site employees. Drinking water is supplied to LLNL by the San Francisco Hetch Hetchy Aqueduct System and the Alameda County Flood and Water Conservation District, Zone 7 (Zone 7). Furthermore, a screening analysis conducted as part of the RCRA closure process shows that the existing levels of contaminants do not pose a threat to ground water (Mansoor et al., 2006). The parameters used to estimate exposure of the bystander worker and construction worker are listed in Table 3; references are provided for the specific values.

For the residential exposure scenario, we assumed that exposure could occur via inhalation of volatile and particulate contaminants present in soil; by incidental ingestion of soil, and by dermal contact and absorption of contaminants from the soil matrix. We did not consider exposure via ingestion of groundwater for the reasons noted above, i.e., Area 514 contaminants are not likely to reach groundwater at concentrations of concern, or in a time frame that is relevant to human health (Mansoor et al., 2006). Furthermore, it is likely that drinking water or water for domestic use would be supplied by the City and County of San Francisco or by Zone 7. Both of these water suppliers offer high quality water without the need for installation and maintenance of a costly water supply well. Similarly, ingestion of homegrown fruits and vegetables was not evaluated as a source of exposure given that (1) home gardens would likely be supplied with clean water from an external source, and (2) it is unlikely that enough produce could be grown on a residential lot to contribute significantly to a resident's diet. Exposure factors used in the residential scenario are given in Table 3.

The equations used to evaluate carcinogenic risk and non-carcinogenic hazard are presented in Table 4 (US EPA, 1989; DTSC, 1994). The cancer slope factors, reference doses, and other chemical specific information for the materials evaluated are listed in Table 5. The hierarchy for the choice of toxicity values is as follows: first tier, OEHHA guidance (OEHHA, 2005; OEHHA, 2000b); second tier, IRIS, U.S. EPA provisional peer reviewed toxicity values, and HEAST. With the exception of petroleum hydrocarbons. the second tier data were obtained from the online database of toxicity data maintained by Oakridge National Laboratory (ORNL, 2005). Toxicity values for petroleum hydrocarbons were obtained from Total Petroleum Hydrocarbon Criteria Working Group (TPHCWG, 1997, p. 9) and ATSDR (1995) as no values were available from the first and second tier sources. 
Table 3. Exposure parameters

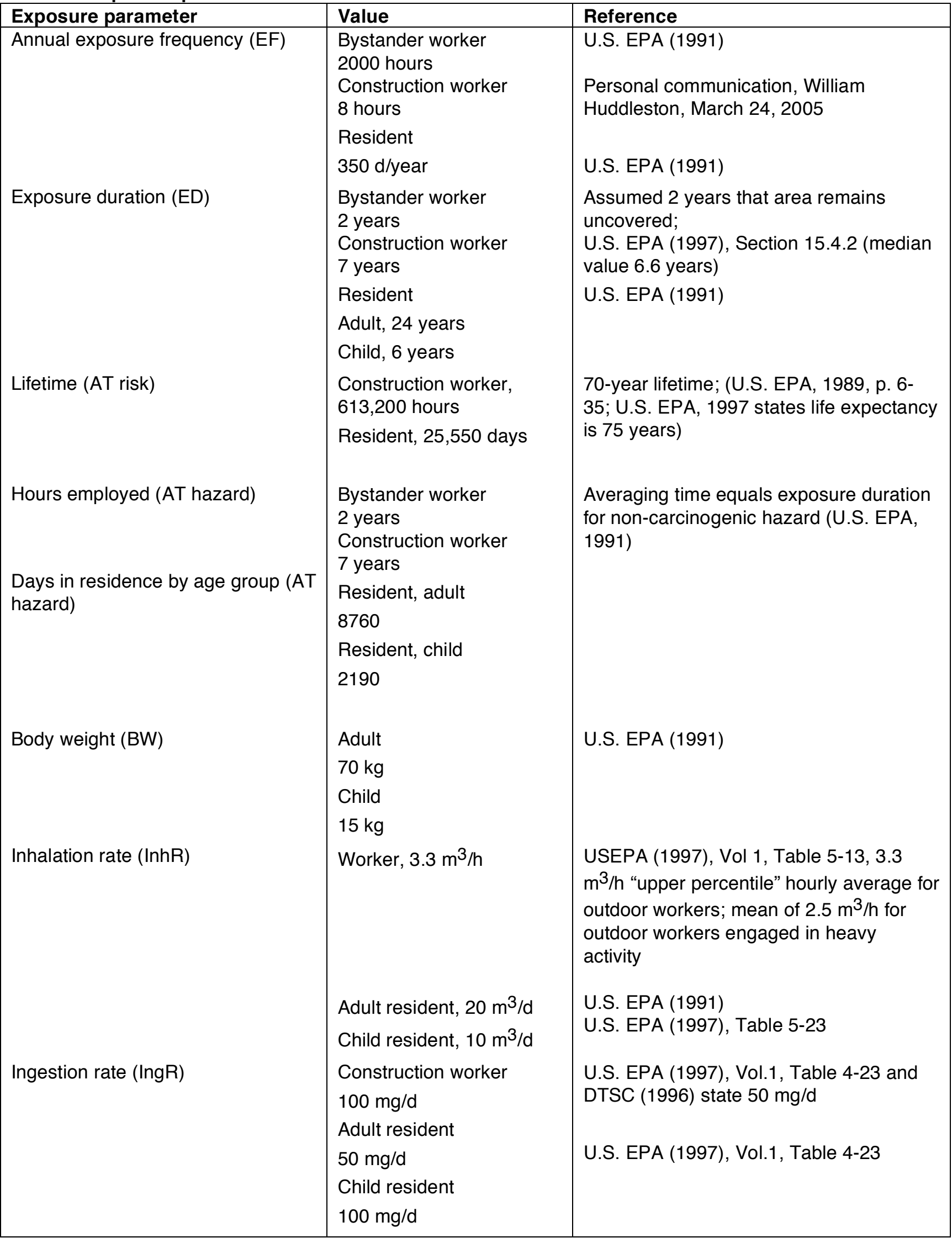


Table 3. Exposure parameters (continued)

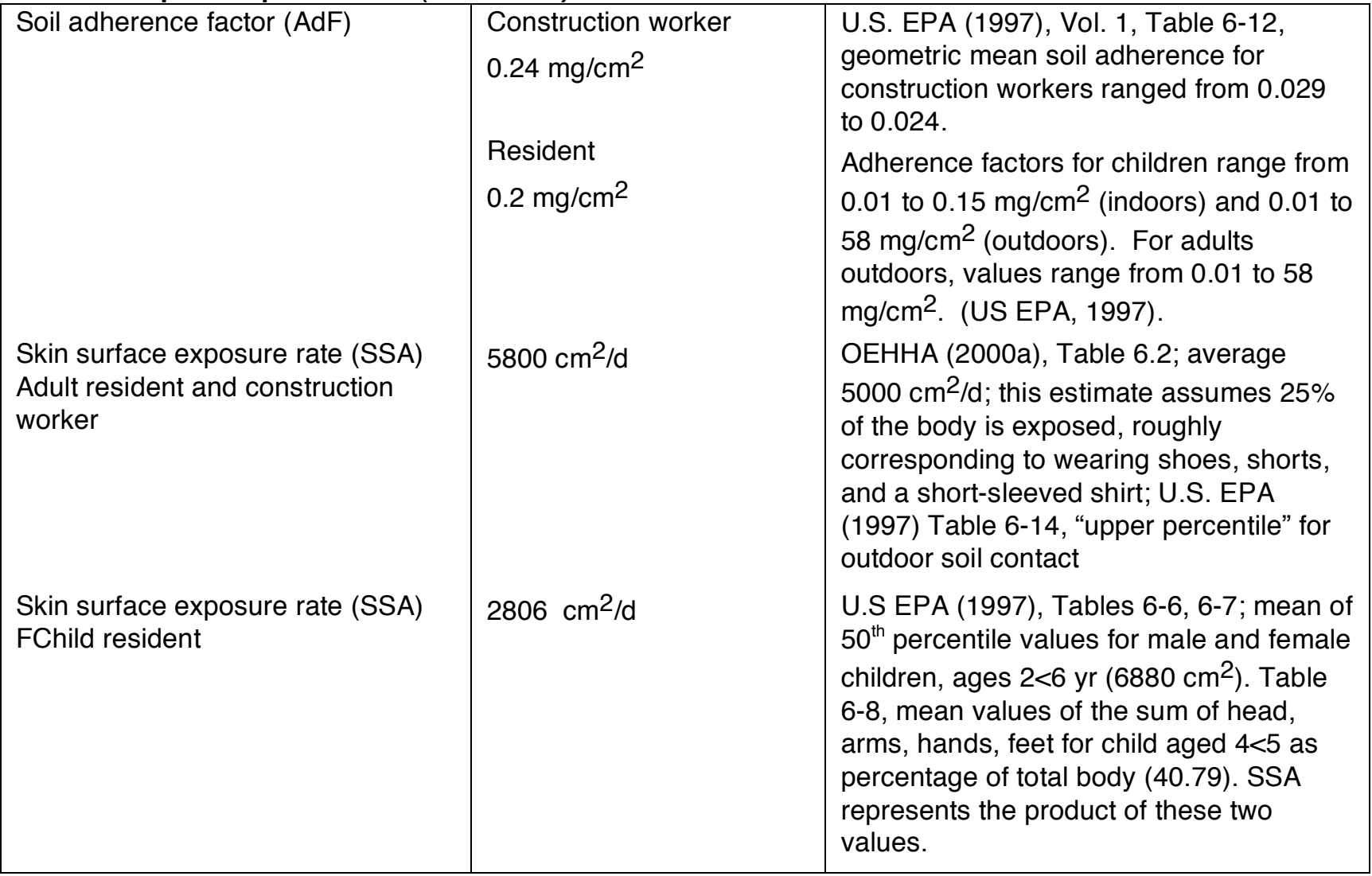

Table 4. Equations used to calculate carcinogenic risk and non-carcinogenic hazard. (Variables are described in Table 3.)

\begin{tabular}{|c|c|}
\hline Risk from inhalation exposure & $S F_{i} \times C_{s} \times \frac{\operatorname{InhR} \times E F \times E D}{B W \times A T}$ \\
\hline Risk from ingestion exposure & $S F_{o} \times C_{s} \times \frac{\operatorname{Ing} R \times E F \times E D \times 10^{-6} \mathrm{mg} / \mathrm{kg}}{B W \times A T}$ \\
\hline Risk from dermal exposure & $S F_{o} \times C_{s} \times \frac{A b F \times A d F \times S S A \times E F \times E D \times 10^{-6} \mathrm{mg} / \mathrm{kg}}{B W \times A T}$ \\
\hline Hazard from inhalation exposure & $\frac{1}{R f D_{i}} \times C_{s} \times \frac{\operatorname{Inh} R \times E F \times E D}{B W \times A T}$ \\
\hline Hazard from ingestion exposure & $\frac{1}{R f D_{o}} \times C_{s} \times \frac{\operatorname{IngR} \times E F \times E D \times 10^{-6} \mathrm{mg} / \mathrm{kg}}{B W \times A T}$ \\
\hline Hazard from dermal exposure & $\frac{1}{R f D_{o}} \times C_{s} \times \frac{A b F \times A d F \times S S A \times E F \times E D \times 10^{-6} \mathrm{mg} / \mathrm{kg}}{B W \times A T}$ \\
\hline
\end{tabular}

Of the exposure factors listed in Table 3, the annual exposure frequency for the intrusive construction worker and the exposure duration for the bystander worker are site specific. The greatest exposure for the area would be connected with trenching for improvements to storm 
drainage in the area. This has been evaluated to be no more than 8 hours per year. Because the future improvements to the area are planned only to be placement of asphalt, it is unlikely that any one individual construction worker will be exposed for more than one year; nevertheless, the risk assessment included the possibility that a person could be exposed in each of seven years. Similarly, it is unlikely that any bystander worker will be exposed to the entire area without any asphalt cover for two working years.

The exposure parameters in Table 3 were used with cancer slope factors and non-carcinogenic reference doses in OEHHA-approved equations (see Table 4) to estimate the risk and noncarcinogenic hazard to the two categories of worker and to a hypothetical resident. For workers, we also compared hourly air concentration estimates to acute relative exposure limits. Estimated cancer risk and non-cancer hazard indices were summed across exposure routes; hazard indices were summed without regard to target organ or system. An example calculation for cancer risk from inhalation for cobalt for the intrusive construction worker is presented below. All calculations are presented in Attachment $\mathrm{C}$ to this document.

Example calculation for cobalt for the intrusive construction worker:

$$
\begin{aligned}
& \text { Risk }=S F_{i} \times C_{s} \times \frac{I n h R \times E F \times E D}{B W \times A T} \\
& \text { Risk }=9.8 \frac{R i s k}{\mathrm{mg} / \mathrm{kg} \cdot \mathrm{d}} \times 2.7 \times 10^{-5} \mathrm{mg} / \mathrm{m}^{3} \times \frac{79 \mathrm{~m}^{3} / \mathrm{d} \times 8 \mathrm{~h} / \mathrm{y} \times 7 \mathrm{y}}{70 \mathrm{~kg} \times 613200 \mathrm{~h}} \\
& \text { Risk }=3 \times 10^{-8}
\end{aligned}
$$

The resulting risks and hazards for all exposure scenarios are summarized in Tables 6 and 7. 
Table 5. Slope factors, reference doses, relative exposure limits, skin absorption fractions for the materials of concern.*

\begin{tabular}{|c|c|c|c|c|c|c|c|}
\hline $\begin{array}{l}\text { Material present at } \\
\text { concentrations above } \\
\text { clean closure }\end{array}$ & $\begin{array}{c}\text { Slope } \\
\text { Factor } \\
\text { Inhalation } \\
\left(\mathrm{SF}_{\mathbf{i}},\right. \\
\text { Risk/mg/k } \\
\mathbf{g} \cdot \mathbf{d})\end{array}$ & $\begin{array}{c}\text { Slope } \\
\text { Factor } \\
\text { Oral } \\
\left(\mathrm{SF} F_{\mathrm{o}}\right. \\
\mathrm{Risk} / \mathrm{mg} / \\
\mathrm{kg} \cdot \mathrm{d})\end{array}$ & $\begin{array}{l}\text { Reference } \\
\text { Dose } \\
\text { Inhalation } \\
\left(\mathbf{R f D}_{\mathbf{i}}\right. \\
\mathrm{mg} / \mathrm{kg} \cdot \mathrm{d})\end{array}$ & $\begin{array}{c}\text { Reference } \\
\text { Dose } \\
\text { Oral } \\
(\mathrm{RfD} \text {, } \\
\mathrm{mg} / \mathrm{kg} \cdot \mathrm{d})\end{array}$ & \begin{tabular}{|c|} 
Acute \\
relative \\
exposure \\
level ††† \\
$(\mathrm{REL}$, \\
$\left.\mu \mathrm{g} / \mathrm{m}^{3}\right)$ \\
\end{tabular} & $\begin{array}{c}\text { Skin } \\
\text { absorption } \\
\text { fraction }\end{array}$ & $\begin{array}{c}\text { PEF† } \\
\text { or } \\
\text { VF } \neq \\
(\mathrm{m} 3 / \mathbf{k g})\end{array}$ \\
\hline Arachlors (PCB) & $2.0 \mathrm{E}+0$ & $5.0 \mathrm{E}+0$ & & $2.0 \mathrm{E}-5$ & & $1.4 \mathrm{E}-1$ & $5.21 \mathrm{E}+5$ \\
\hline Benzene & $1.0 \mathrm{E}-1$ & $1.0 \mathrm{E}-1$ & $1.7 \mathrm{E}-2$ & $4.0 \mathrm{E}-3$ & $1.3 \mathrm{E}+3$ & $1.0 \mathrm{E}-2$ & $4.15 E+3$ \\
\hline Beryllium & 8.4E+0 & $4.3 \mathrm{E}+0$ & $2.0 \mathrm{E}-6$ & $2.0 \mathrm{E}-3$ & & $1.0 \mathrm{E}-3$ & $1.32 \mathrm{E}+9$ \\
\hline bis-2-Ethylhexyl phthlate & $8.4 \mathrm{E}-3$ & $3.0 \mathrm{E}-3$ & & $2.0 \mathrm{E}-2$ & & $1.0 \mathrm{E}-2$ & $1.89 \mathrm{E}+7$ \\
\hline Bromomethane & & & $1.4 \mathrm{E}-3$ & $1.4 \mathrm{E}-3$ & $3.9 \mathrm{E}+3$ & $1.0 \mathrm{E}-2$ & $1.95 E+3$ \\
\hline Carbon tetrachloride & $1.5 \mathrm{E}-1$ & $1.5 \mathrm{E}-1$ & $1.1 \mathrm{E}-2$ & $7.0 \mathrm{E}-4$ & $1.9 \mathrm{E}+3$ & $1.0 \mathrm{E}-2$ & $1.44 \mathrm{E}+3$ \\
\hline Chloroform & $1.9 \mathrm{E}-2$ & 3.1E-2 & $8.6 \mathrm{E}-2$ & $1.0 \mathrm{E}-2$ & $1.5 \mathrm{E}+2$ & $1.0 \mathrm{E}-2$ & $2.56 \mathrm{E}+3$ \\
\hline Chloromethane & $6.3 \mathrm{E}-3$ & $1.3 \mathrm{E}-2$ & $2.8 \mathrm{E}-1$ & & & $1.0 \mathrm{E}-2$ & $1.30 \mathrm{E}+3$ \\
\hline Chromium & & & & $1.5 \mathrm{E}+0$ & & $1.0 \mathrm{E}-3$ & $1.32 \mathrm{E}+9$ \\
\hline Chromium, hexavalent & $5.1 \mathrm{E}+2$ & & $5.7 \mathrm{E}-5$ & $3.0 \mathrm{E}-3$ & & $1.0 \mathrm{E}-3$ & $1.32 \mathrm{E}+9$ \\
\hline Cobalt & $9.8 \mathrm{E}+0$ & & $5.7 \mathrm{E}-6$ & $2.0 \mathrm{E}-2$ & & $1.0 \mathrm{E}-3$ & $1.32 \mathrm{E}+9$ \\
\hline Copper & & & & $4.0 \mathrm{E}-2$ & $1.0 \mathrm{E}+2$ & $1.0 \mathrm{E}-3$ & $1.32 \mathrm{E}+9$ \\
\hline Dibutyl phthlate & & & & $1.0 \mathrm{E}-1$ & & $1.0 \mathrm{E}-2$ & $7.97 \mathrm{E}+5$ \\
\hline Mercury & & & $2.6 \mathrm{E}-5$ & $3.0 \mathrm{E}-3$ & $1.8 \mathrm{E}+0$ & $1.0 \mathrm{E}-3$ & $1.32 \mathrm{E}+9$ \\
\hline Methylene chloride & $3.5 \mathrm{E}-3$ & $1.4 \mathrm{E}-2$ & $4.0 \mathrm{E}-1$ & $6.0 \mathrm{E}-2$ & $1.4 \mathrm{E}+4$ & $1.0 \mathrm{E}-2$ & $2.46 \mathrm{E}+3$ \\
\hline Methyl ethyl ketone & & & $1.4 \mathrm{E}+0$ & $6.0 \mathrm{E}-1$ & $1.3 E+4$ & $1.0 \mathrm{E}-2$ & $1.40 \mathrm{E}+4$ \\
\hline Methyl isobutyl ketone & & & $8.6 \mathrm{E}-1$ & $8.0 \mathrm{E}-2$ & & $1.0 \mathrm{E}-2$ & $1.09 \mathrm{E}+4$ \\
\hline Nickel & $9.1 \mathrm{E}-1$ & & $1.4 \mathrm{E}-5$ & $2.0 \mathrm{E}-2$ & $6.0 \mathrm{E}+0$ & $1.0 \mathrm{E}-3$ & $1.32 \mathrm{E}+9$ \\
\hline $\begin{array}{l}\text { Petroleum hydrocarbons } \\
\text { as diesel }\end{array}$ & & & $2.9 \mathrm{E}-1$ & $1.0 \mathrm{E}-1$ & $2.0 \mathrm{E}+1 \dagger+\dagger$ & & \\
\hline Silver & & & & $5.0 \mathrm{E}-3$ & & $1.0 \mathrm{E}-3$ & $1.32 \mathrm{E}+9$ \\
\hline Tetrachloroethene (PCE) & $2.1 \mathrm{E}-2$ & $5.4 \mathrm{E}-1$ & $1.0 \mathrm{E}-2$ & $1.0 \mathrm{E}-2$ & $2.0 \mathrm{E}+4$ & $1.0 \mathrm{E}-2$ & $2.26 \mathrm{E}+3$ \\
\hline Toluene & & & 8.6E-2 & $2.0 \mathrm{E}-1$ & $3.7 \mathrm{E}+4$ & $1.0 \mathrm{E}-2$ & $4.75 e+03$ \\
\hline Trichloroethane 1,1,1- & & & $6.3 \mathrm{E}-1$ & $2.0 \mathrm{E}-1$ & $6.8 \mathrm{E}+4$ & $1.0 \mathrm{E}-2$ & $1.70 \mathrm{E}+3$ \\
\hline Trichloroethene (TCE) & 7.0E-3 & $1.3 \mathrm{E}-2$ & 1.7E-2 & $3.0 \mathrm{E}-4$ & & $1.0 \mathrm{E}-2$ & $2.35 E+3$ \\
\hline Vanadium & & & & $7.0 \mathrm{E}-3$ & $3.0 \mathrm{E}+1$ & $1.0 \mathrm{E}-3$ & $1.32 E+9$ \\
\hline Xylenes & & & $2.0 \mathrm{E}-1$ & $2.0 \mathrm{E}-1$ & $2.2 \mathrm{E}+4$ & $1.0 \mathrm{E}-2$ & $6.63 E+3$ \\
\hline Zinc & & & & $3.0 \mathrm{E}-1$ & & $1.0 \mathrm{E}-3$ & $1.32 \mathrm{E}+9$ \\
\hline
\end{tabular}

*Inhalation and oral slope factors from OEHHA (2005a, in boldface) and ORNL (2005); inhalation and oral reference doses from OEHHA [2005b, calculated from chronic inhalation values or RELs (x $20 \mathrm{~m} 3 / \mathrm{d}$ x 1/70 kg), in boldface], TPHCWG (1997) for petroleum hydrocarbons, and ORNL (2005) for all others. Skin absorption fractions from ORNL (2005); note that skin absorption fraction used for dibutyl phthlate was derived for diethyl phthlate, and that the value listed for Petroleum hydrocarbons is for Total petroleum hydrocarbons (aromatic low). t†† Acute Minimum Risk Level (MRL) from ATSDR (1995). acute relative exposure levels from OEHHA (2000b in boldface).

†PEF for incidental worker is 1.32E+9, U.S. EPA (1996). PEF for intrusive construction worker is 1.44E+6, which was determined from the U.S. EPA (1995) emission factor of 1.2 tons/acre/month for construction work and equations in U.S. EPA (1996).

¥VFs calculated in conformance with U.S. EPA (1996), based on data in MDEQ (2003) for petroleum hydrocarbons and ORNL (2005) for all others. 


\section{Uncertainties and Conservatisms}

Quantification of exposure involves estimating the magnitude, frequency, and duration of exposure for the receptors for exposure pathways of concern. This risk assessment has implemented high-end estimates for each of these three factors.

First there are conservatisms as to the magnitude of the concentrations of the constituents in soils. The soil concentrations were represented by the 95\% UCL on the mean of detections, which is a conservative estimate of the soil concentration.

Table 6. Summary of carcinogenic risks and hazards for all materials.

\begin{tabular}{|c|c|c|c|c|c|}
\hline $\begin{array}{l}\text { Assessment } \\
\text { end point }\end{array}$ & Pathway & $\begin{array}{l}\text { Bystander } \\
\text { worker }\end{array}$ & $\begin{array}{l}\text { Percent } \\
\text { contribution } \\
\text { of highest } \\
\text { contributing } \\
\text { constituent }\end{array}$ & $\begin{array}{l}\text { Intrusive } \\
\text { construction } \\
\text { worker }\end{array}$ & $\begin{array}{l}\text { Percent } \\
\text { contribution } \\
\text { of highest } \\
\text { contributing } \\
\text { constituent }\end{array}$ \\
\hline $\begin{array}{l}\text { Carcinogenic } \\
\text { risk }\end{array}$ & $\begin{array}{l}\text { Inhalation } \\
\text { Ingestion } \\
\text { Dermal } \\
\quad \text { Total }\end{array}$ & $\begin{array}{l}9 \times 10^{-9} \\
9 \times 10^{-9}\end{array}$ & $25 \%$ cobalt & $\begin{array}{l}4 \times 10^{-8} \\
3 \times 10^{-10} \\
2 \times 10^{-10} \\
4 \times 10^{-8}\end{array}$ & $\begin{array}{l}64 \% \text { cobalt } \\
71 \% \\
\text { beryllium } \\
98 \% \text { PCB }\end{array}$ \\
\hline Chronic hazard & $\begin{array}{l}\text { Inhalation } \\
\text { Ingestion } \\
\text { Dermal } \\
\quad \text { Total }\end{array}$ & $\begin{array}{l}2 \times 10^{-2} \\
2 \times 10^{-2}\end{array}$ & $\begin{array}{l}87 \% \mathrm{PHC} \text { as } \\
\text { diesel }\end{array}$ & $\begin{array}{l}8 \times 10^{-3} \\
2 \times 10^{-5} \\
2 \times 10^{-5} \\
8 \times 10^{-3}\end{array}$ & $\begin{array}{l}65 \% \text { cobalt } \\
26 \% \\
\text { vanadium } \\
96 \% \text { PCB }\end{array}$ \\
\hline Acute hazard & Inhalation & $9 \times 10^{-1}$ & $\begin{array}{l}\sim 100 \% \mathrm{PHC} \\
\text { as diesel }\end{array}$ & $9 \times 10^{-1}$ & $\begin{array}{l}\sim 100 \% \mathrm{PHC} \\
\text { as diesel }\end{array}$ \\
\hline
\end{tabular}

Note: Numbers are rounded.

Table 7. Summary of carcinogenic risks and hazards for the residential exposure scenario (numbers in table have been rounded).

\begin{tabular}{|l|l|l|}
\hline & Percent contribution of \\
Assessment end point & Pathway & $\begin{array}{l}\text { Perghest contributing } \\
\text { constituent }\end{array}$ \\
\hline Carcinogenic risk & Inhalation $1.7 \times 10^{-7}$ & $48 \%$ PCBs \\
& Ingestion $5.0 \times 10^{-7}$ & $99 \%$ PCBs \\
& Dermal $7.6 \times 10^{-7}$ & $\sim 100 \%$ PCBs \\
& Total $1 \times 10^{-6}$ a & $\sim 90 \%$ PHC as diesel \\
& Inhalation $6.6 \times 10^{-2}$ & $34 \%$ PCBs \\
& Ingestion $1.3 \times 10^{-1}$ & $97 \%$ PCBs \\
& Dermal $4.7 \times 10^{-2}$ & \\
\hline
\end{tabular}

${ }^{a}$ Value listed represents the estimated cancer risk when contaminant concentrations and/or the set of contaminants have been adjusted to account for background levels. When no adjustments for background concentrations are made, the estimated cancer risk is $3 \times 10^{-6}$ 
Second, there are conservatisms as to the level of exposure. With respect to workers, "upper percentile" inhalation rates for construction and bystander workers, an incidental soil ingestion rate twice the recommended value, and a dermal exposure rate that includes the unlikely exposure due to wearing shorts were selected to represent the possible exposures.

As to exposure duration, the 8-hour exposure for the intrusive construction worker was intentionally chosen to be conservative. Although the contemplated work should only take about 4 hours, an 8-hour exposure was chosen to provide an upperbound estimate on the exposure duration for this receptor.

The exposure frequency assumptions are similarly health conservative. For the construction worker, it was assumed that trenching work could occur in each of seven years, although it is highly unlikely that the work will occur more than once. Likewise, the assumption that the area will remain uncovered for two years is likely an overestimate of the period of time that the area will remain uncovered.

The residential exposure scenario calculations are based on the assumption that Area 514 would be occupied and used continuously as a residence over a 30-year period. This scenario would occur only if the DOE relinquished ownership of the Livermore site, and an individual subsequently chose to build and occupy a home in the specific location of Area 514. Given the industrial character of the site, this does not seem to represent a particularly credible scenario. Furthermore, considering the level of investment by DOE in infrastructure at LLNL, the expectation of continued operations at the Livermore site, and DOE's commitment to and responsibility for protection of public health, it appears that the future residential occupancy of this area is unlikely. Nonetheless, if residential occupancy of the site were to occur in the future, our evaluation indicates that adverse health effects are not a likely outcome.

Quantification of toxic effects involves applying appropriate toxicity data to the constituents of potential concern. However, not all constituents measured at Area 514 have specific toxicity data. For example, cobalt was included as a constituent of concern even though the toxicity data for cobalt have been developed for cobalt dust and the cobalt in soil is most likely not present in that particular form. Nickel and mercury toxicity data were used in the same way, that is to say, even though the materials at Area 514 are not documented to be present in the forms for which toxicity data are available, the risk assessment treats them as if they are, yielding a health conservative result. For ease of presentation and to be health conservative, all arachlors (PCBs) were treated as if they had the highest toxicity value for any detected arachlor, without regard to speciation. Finally, all noncarcinogenic hazard quotients were added together for an overall hazard estimate without regard to toxic endpoint.

One of the COPCs is represented by an analytical result reported as 'total petroleum hydrocarbons as diesel'. In the absence of detailed information on the composition of this mixture, but with the knowledge that no aromatics associated with diesel were detected, we represented 'total petroleum hydrocarbons as diesel' as aliphatic compounds with 8 to 16 
carbon atoms. This enabled the use of oral and inhalation reference doses developed by the Total Petroleum Hydrocarbon Criteria Working Group (TPHCWG, 1997). We also identified an acute inhalation Minimum Risk Level (MRL) from the ATDSR (1995) for fuel oil 2 as an appropriate value for estimating the potential effects of acute exposure to this material. It is recognized that diesel fuel is a highly variable mixture of petroleum hydrocarbons, and that it is not certain that the material present in soils at Area 514 are comparable to those found in fuel oil 2. However, the ATSDR (1995) notes that "diesel fuels are approximately similar to fuel oils used for heating (fuel oils no. 1, no. 2, and no. 4)." The International Agency for Research on Cancer (IARC, 1989) determined that marine diesel fuel is "possibly carcinogenic to humans (Group 2B)", but that "distillate (light) diesel fuels are not classifiable as to their carcinogenicity to humans (Group 3)". As far as can be determined, no cancer slope factors doses have been developed to evaluate potential carcinogenic health effects associated with exposure to diesel.

Studies of the compounding of conservatism in probabilistic risk assessments show that setting as few as two factors at high end levels (e.g., near the $90^{\text {th }}$-percentile), while the remaining variables are set at less conservative, or typical values results in a product of all input variables that approximate a maximum exposure value (e.g., 99th - percentile value) (Cullen 1994). This risk assessment uses near $90^{\text {th }}$-percentile estimates for contaminant concentrations, inhalation rates, ingestion rates, and skin surface exposure. As a result it provides very conservative estimates of health effects that are, nonetheless, below any level of concern.

\section{Summary of Risks and Hazards}

The calculations in this risk assessment are based on conservative assumptions for nearly every parameter, which yields a very conservative upper bound estimate of potential health effects. The calculations demonstrate that even though 29 constituents of potential concern were present in detectable levels, they do not constitute a health risk: the estimated carcinogenic risk is less than or equal to one in one million, and the acute and chronic hazard indices are less than 1 . These values are all below levels of health concern, and support the conclusion that clean closure of the area for RCRA is appropriate. 


\section{References}

Abri, Mohammad, Closure Plan for the Area 514 Treatment and Storage Facility, Lawrence Livermore National Laboratory, Livermore, CA, UCRL-AR-138271-REV-1 (2004).

Agency for Toxic Substances Disease Registry (ATSDR), Toxicological Profile for Fuel Oils, U.S. Department of Health and Human Services, Public Health Service. June 1995.

Cullen, Alison C., "Measures of Compounding Conservatism in Probabilistic Risk Assessment," Risk Analysis, 14(4): 389-393 (1994).

Department of Toxic Substances Control (DTSC), Preliminary Endangerment Assessment Guidance Manual, State of California Environmental Protection Agency, Department of Toxic Substances Control (1994).

Department of Toxic Substances Control (DTSC), Supplemental Guidance for Human Health Multimedia Risk Assessments of Hazardous Waste Sites and Permitted Facilities, State of California Environmental Protection Agency, Department of Toxic Substances Control, Office of Scientific Affairs (1996).

Department of Toxic Substances Control (DTSC), Human and Ecological Risk Division, Selecting Inorganic Constituents as Chemicals of Potential Concern at Risk Assessments at Hazardous Waste Sites and Permitted Facilities; Final Policy, (February 1997).

Dreicer, Mona, Preliminary Report of the Past and Present Uses, Storage, and Disposal of Hazardous Materials at the Lawrence Livermore National Laboratory, Lawrence Livermore National Laboratory, Livermore, CA, UCID-20442 (1985).

Folks, Karen, Technical Report Supporting LLNL Report of Waste Discharge for Beneficial Reuse of Soil at the Livermore Site, Lawrence Livermore National Laboratory, Livermore, CA, UCRL-AR-126943 (1997).

Huddleston, William, LLNL Engineer, personal communication, March 24, 2005.

International Agency for Research on Cancer (IARC). Volume 45. Occupational Exposures in Petroleum Refining: Crude Oil and Major petroleum Fuels. World Health Organization, IARC. IARC Monographs on the Evaluation of Carcinogenic Risks to Humans. 1989.

Mansoor, Kayyum, Zafir Demir, and Charles Noyes, "Analysis of Potential Impact to Ground water from Residual Soil Contamination in Area 514 Livermore Site," Lawrence Livermore National Laboratory, Livermore, CA, UCRL-AR-220581 (2006).

Montana Department of Environmental Quality (MDEQ, 2003), Montana Tier 1 Risk-Based Corrective Action Guidance for Petroleum Releases, October 2003, http://www.deq.state.mt.us/LUST/TechGuidDocs/techguidlist.asp . 
Oak Ridge National Laboratory, The Risk Assessment Information System, Chemical-Specific Toxicity Values, http://risk.lsd.ornl.gov/, accessed August 24, 2005. This database contains information taken from the United States Environmental Protection Agency's (EPA's) Integrated Risk Information System (IRIS ), the Health Effects Assessment Summary Tables (HEAST-rad HEAST-nonrad), EPA Provisional Peer Reviewed Toxicity Values (PPRTVs) Database, and other information sources. In this database, all information is referenced.

Office of Environmental Health Hazard Assessment (OEHHA), Technical Support Document for Exposure Assessment and Stochastic Analysis, September 2000a).

Office of Environmental Health Hazard Assessment (OEHHA), All Acute Reference Exposure Levels Developed by OEHHA as of May 2000, http://www.oehha.ca.gov/air/acute rels/allAcRELs.html (2000b).

Office of Environmental Health Hazard Assessment (OEHHA), Cal/EPA - OEHHA Toxicity Criteria Database August 10, 2005, http://www.oehha.ca.gov/risk/ChemicalDB/ (2005a).

Office of Environmental Health Hazard Assessment (OEHHA), All Chronic Reference Exposure Levels Adopted by OEHHA as of February 2005, http://www.oehha.ca.gov/air/chronic_rels/AllChrels.html (2005b).

Total Petroleum Hydrocarbon Criteria Working Group (TPHCWG) (1997), Development of Fraction Specific Reference Doses (RfDs) and Reference Concentrations (RfCs) for Total Petroleum Hydrocarbons (TPH), Prepared by Exxon Biomedical Sciences, Inc.: D.A. Edwards, M.D. Andriot, M.A. Amoruso, A.C. Tummey, C.J. Bevan, A. Tveit, L.A. Hayes; EA Engineering, Science, and Technology, Inc.: S.H. Youngren; Remediation Technologies, Inc.: D.V. Nakles, Amherst Scientific Publishers, Amherst, Massachusetts.

United States Environmental Protection Agency (U.S. EPA), Risk Assessment Guidance for Superfund, Vol. 1, Human Health Evaluation Manual (Part A), United States Environmental Protection Agency, Office of Solid Waste and Emergency Response, Washington, DC (EPA/540/1-89/002; PB90-155581, December 1989).

United States Environmental Protection Agency (U.S. EPA), Risk Assessment Guidance for Superfund, Vol. 1, Human Health Evaluation Manual, Supplemental Guidance, "Standard Default Exposure Factors, ” Interim Final, United States Environmental Protection Agency, Office of Emergency and Remedial Response, Toxics Integration Branch, Washington, DC (OSWER Directive: 9285.6-03, March 25, 1991).

United States Environmental Protection Agency (U.S. EPA), Supplemental Guidance to RAGS: Calculating the Concentration Term, United States Environmental Protection Agency, Office of Solid Waste and Emergency Response, Washington, DC (PB92-963373, 1992)

USEPA, 1995, Compilation of Air Pollutant Emission Factors, Volume 1: Stationary Point and Area, Sources, Chapter 13, Miscellaneous Sources, U.S. Environmental Protection Agency, Office of Air and Radiation, Publication No. AP-42, Fifth Edition, 1995.

http://www.epa.gov/ttn/chief/ap42/ch13/index.html 
United States Environmental Protection Agency (U.S. EPA), Soil Screening Guidance: User's Guide, United States Environmental Protection Agency, Office of Solid Waste and Emergency Response, Washington, DC (Publication 9355.4-23, July 1996).

United States Environmental Protection Agency (U.S. EPA), Exposure Factors Handbook, United States Environmental Protection Agency, Office of Research and Development, National Center for Environmental Assessment, Washington, DC (EPA/600/P-95/002Fa, August 1997).

United States Environmental Protection Agency (U.S. EPA), Calculating Upper Confidence Limits for Exposure Point Concentrations at Hazardous Waste Sites, United States Environmental Protection Agency, Office of Emergency and Remedial Response, Washington, DC 20460 (OSWER 9285.6-10, December 2002). 


\section{Attachment A. Development of LLNL-Specific Screening Values}

Lawrence Livermore National Laboratory (LLNL) is a research and development institution for science and technology applied to national security. LLNL's Livermore site occupies an area of 1.3 square miles at the eastern boundary of the City of Livermore. LLNL has hundreds of permanent and temporary buildings, with various associated construction, maintenance and landscaping activities. Projects that generate excess soil include, but are not limited to

- fence post digging,

- utility project trenching,

- trailer installation.

- parking lot construction or modifying,

- new building construction,

- old building expansion,

- trailer demolition,

- landscaping, and

- storm drain regrading and maintenance.

As part of LLNL's aggressive waste minimization program, LLNL beneficially reuses excess soils as backfill, and in other projects at the Livermore Site. By attempting to balance soil use as much as possible on-site, LLNL minimizes the amount of excess soils disposed of at municipal landfills, reduces fuel consumption and reduces the amount of soils purchased as fill.

To properly implement its soil reuse program, LLNL developed Livermore-site-specific background values for constituents of concern (Folks, 1997). The background concentration distribution for each constituent was developed by fitting, when supported by sufficient data, a statistical distribution to the background data collected from soil sampling at Livermore Site. The distribution was developed for each metal separately. Developing statistically based background concentration levels was based on two key assumptions:

- The data used truly are from uncontaminated soils.

- The statistical model fits present and future data reasonably well.

The first assumption was met by screening the soil sampling data used in the data distribution. Samples associated with historical activities that resulted in known areas of contamination for any constituent (whether metal or organic) were eliminated. Samples from areas associated with other activities that also could contribute metal contamination, like parking lots, were also eliminated. The remaining data set represented uncontaminated soil.

The second assumption was met by using as much historical data as possible and mathematically transforming the data to achieve the best possible fit to the normal distribution.

A $99.5 \%$ upper prediction limit was selected to define background screening values. Given the above assumptions, about one out of every 200 samples from uncontaminated sites will exceed the statistically based screening value. Such samples will be incorrectly declared 
contaminated until a further evaluation is completed showing location of the sample is unlikely to be contaminated. The likelihood of correctly identifying samples from contaminated areas will depend on the degree of contamination, and therefore, cannot be determined in advance.

Soil samples with non-detectable levels of metals can either indicate the metal is not present in the sample (the concentration is zero), or the metal is actually present in the sample but at a concentration below the detection limit. There are two possible approaches to modeling this data to predict its upper limit: 1) fit a distribution to the detections only, or 2) take into account the percentage of non-detections when fitting the distribution. Case 1 is the appropriate model fitting the assumption that non-detections represent zero concentration. Case 2 is the appropriate model fitting the assumption that the metal is present but below the reporting level (i.e., contractual level below which the analytical laboratory is not required to provide a specific value for the sample, but only that the sample contains less than that level). Case 2 was followed in developing the LLNL statistically calculated background. Because metals are naturally present in soils, when the analytical lab reported the metal was not detected at a concentration above the analytical reporting limit, the nondetections (i.e., less than reporting limit values) are included when fitting the data to a distribution and calculating the 99.5 percentile.

Table A-1 presents the number of analyses, the number of detections, the maximum detection, and the screening value for surface soils (zero to 12 feet deep) calculated for total metals in Livermore Site soil.

Table A-1. Screening value support data.

\begin{tabular}{|c|c|c|c|c|c|}
\hline Constituent & $\begin{array}{l}\text { Number of } \\
\text { samples }\end{array}$ & $\begin{array}{l}\text { Number of } \\
\text { detections }\end{array}$ & $\begin{array}{c}\text { Transformation } \\
\text { to normal } \\
\text { distribution }^{*}\end{array}$ & $\begin{array}{c}\text { Approximate } \\
50 \% \text { ile of } \\
\text { distribution* }\end{array}$ & $\begin{array}{c}\text { Screening } \\
\text { levelt }\end{array}$ \\
\hline $\begin{array}{l}\text { Metals and } \\
\text { metalloids } \\
\text { Antimony } \\
\text { Arsenic } \\
\text { Barium } \\
\text { Beryllium } \\
\text { Cadmium } \\
\text { Chromium } \\
\text { Chromium VI } \\
\text { Cobalt } \\
\text { Copper } \\
\text { Lead } \\
\text { Mercury } \\
\text { Molybdenum } \\
\text { Nickel } \\
\text { Selenium } \\
\text { Silver } \\
\text { Thallium } \\
\text { Vanadium } \\
\text { Zinc }\end{array}$ & $\begin{array}{l}162 \\
162 \\
162 \\
162 \\
162 \\
242 \\
\\
\\
\\
162 \\
162 \\
162 \\
161 \\
162 \\
162 \\
162 \\
162 \\
162 \\
162 \\
162 \\
\end{array}$ & $\begin{array}{l}3 \\
162 \\
162 \\
30 \\
33 \\
242 \\
\\
\\
158 \\
160 \\
61 \\
23 \\
1 \\
162 \\
0 \\
1 \\
2 \\
162 \\
162\end{array}$ & $\begin{array}{l}\text { Boxcox (0.3) } \\
\text { Boxcox (0.7) } \\
\text { Boxcox (0.8) } \\
\text { Boxcox (1.3) } \\
\text { Boxcox (0) } \\
\text { Boxcox (0) } \\
\text { Boxcox (0) } \\
\text { Boxcox (0.4) } \\
\text { Boxcox (0) } \\
\text { Boxcox (0) } \\
\text { Boxcox (0.5) } \\
\text { Boxcox (0) }\end{array}$ & $\begin{array}{c}2.7 \\
182 \\
0.24 \\
36 \\
\\
9.5 \\
16 \\
7 \\
\\
\\
37 \\
\\
0.5 \\
\\
34 \\
40\end{array}$ & $\begin{array}{c}1.12 \\
8.51 \\
308 \\
0.62 \\
1.59 \\
72.4 \\
\text { Any detection } \\
14.6 \\
62.5 \\
43.7 \\
0.14 \\
2.5 \\
82.8 \\
0.4 \\
2.5 \\
0.5 \\
65.2 \\
75.3\end{array}$ \\
\hline
\end{tabular}

* Blanks indicate small sample size or varying detection limits.

† Screening levels are the 99.5 confidence level of the measured values or the reporting limit 
The DTSC reviewed this approach to determining background screening levels and concurred that it was appropriate for use in evaluating the contaminant levels at Area 514. 
Attachment B. Area 514 Soil Concentrations

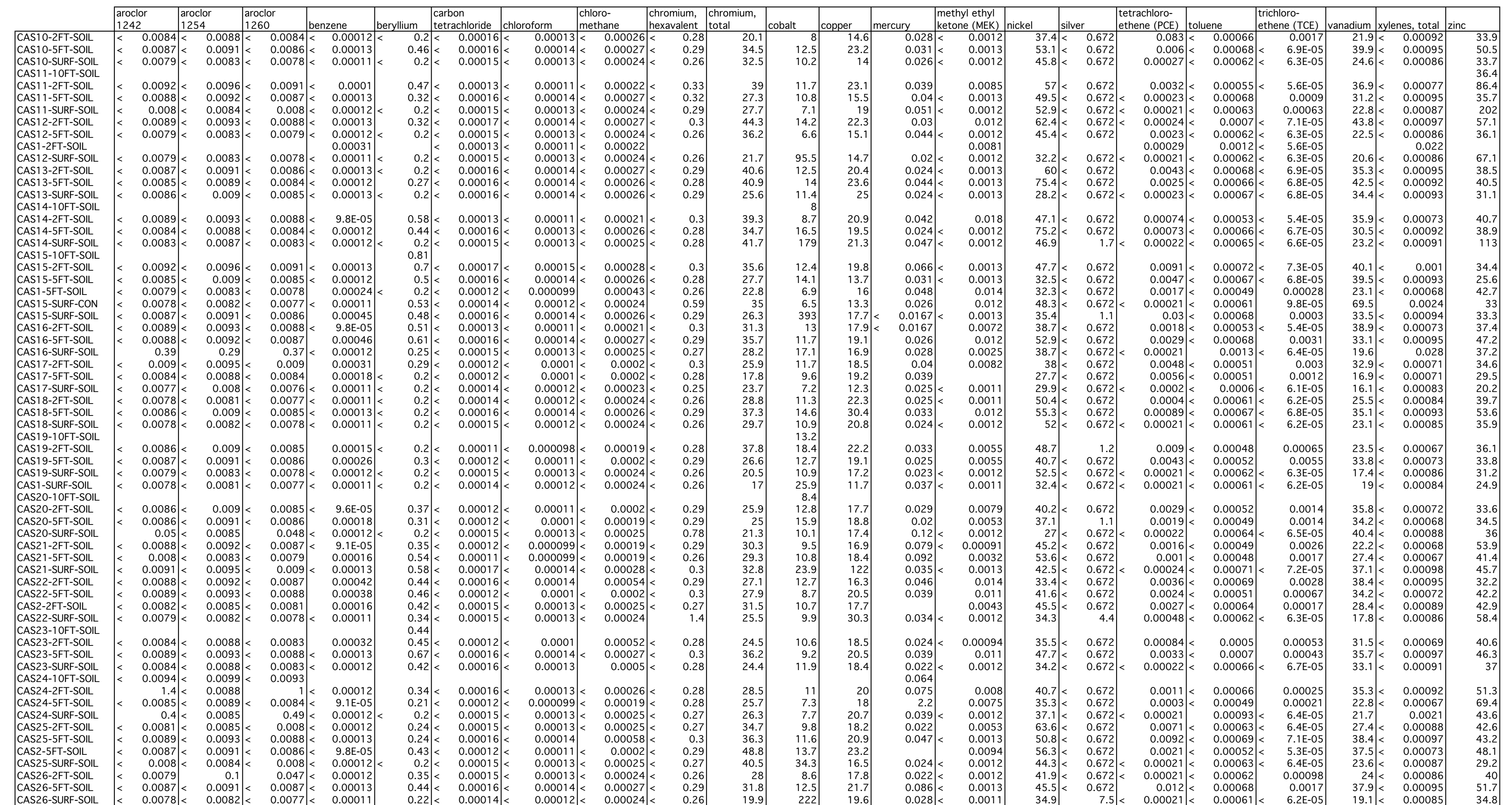




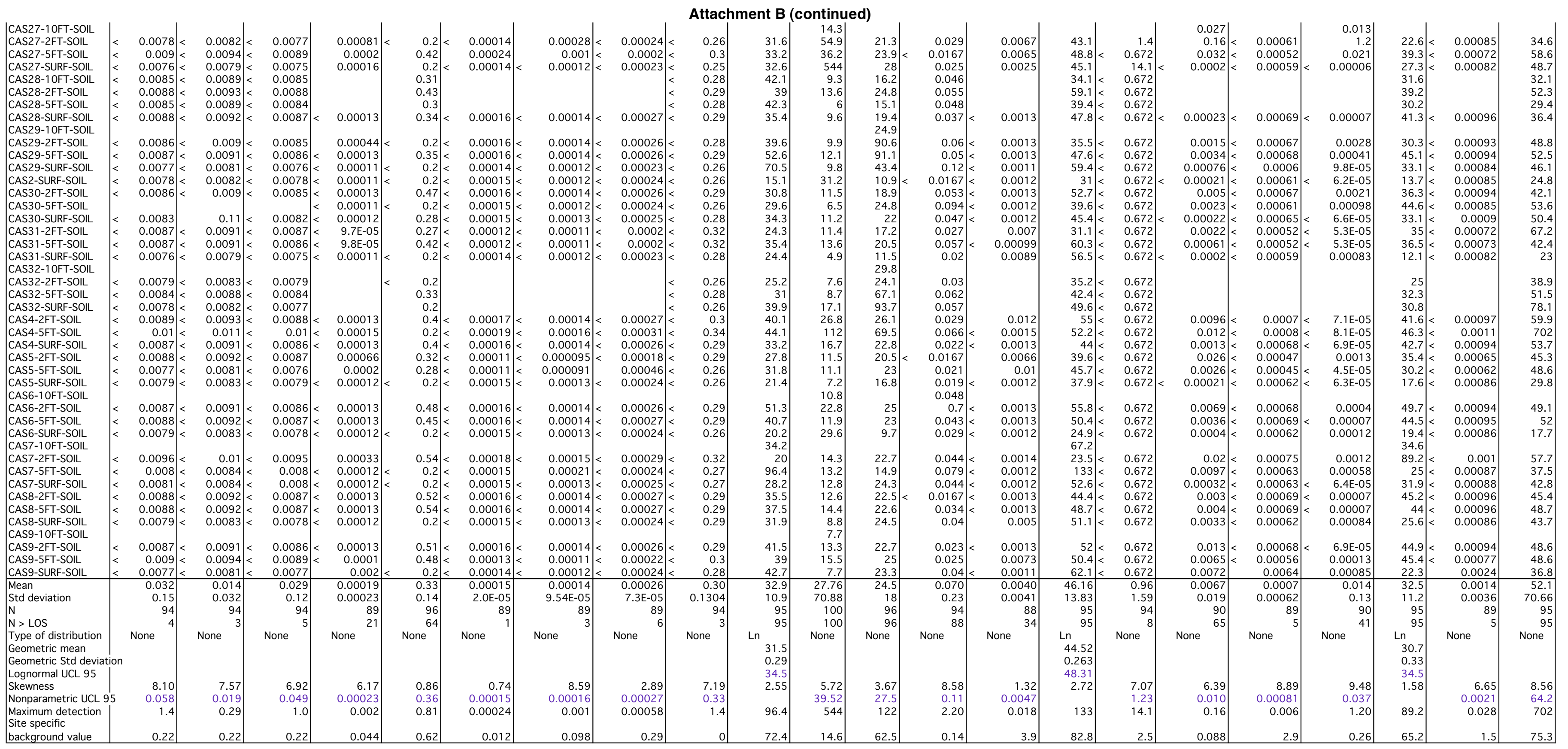


Attachment C. Area 514 Risk and Hazard Calculations

\begin{tabular}{|c|c|c|c|c|c|c|c|c|c|c|c|c|c|}
\hline \multirow{2}{*}{ Inhalation Pathway Calculations } & & & & \multirow{2}{*}{\multicolumn{3}{|c|}{ |DETERMINATION OF EXCESS CANCER RISK: }} & \multirow{2}{*}{\multicolumn{3}{|c|}{ DETERMINATION OF NONCARCINOGENIC HAZARD: }} & & & & \\
\hline & & & & & & & & & & \multicolumn{4}{|c|}{ DETERMINATION OF ACUTE EXPOSURE: } \\
\hline \multicolumn{2}{|c|}{ Bystander worker (work assignment near Area 514) } & & & \multirow{2}{*}{\multicolumn{2}{|c|}{ Exposure frequency (EF; workhours/y) }} & 2,000 & \multirow{2}{*}{\multicolumn{2}{|c|}{\begin{tabular}{|l|} 
Exposure frequency (EF; workhours/y) \\
Exposure duration (ED; y of work)
\end{tabular}}} & 2,000 & \multirow{2}{*}{\multicolumn{3}{|c|}{\begin{tabular}{|l} 
Birect comparison of air concentrations \\
to acute relative exposure limits (RELs)
\end{tabular}}} & \\
\hline & & & & & & & & & & & & & \\
\hline & & & & \multicolumn{2}{|c|}{ Averaging time (AT; hours in lifetime) } & 613,200 & \multicolumn{2}{|c|}{ Averaging time (AT; hours) } & 17,520 & & & & \\
\hline & & & & \multicolumn{2}{|c|}{ Body weight (BWadult; kg) } & & \multicolumn{2}{|c|}{ Body weight (BWadult; kg) } & & & \\
\hline & & & & \multicolumn{2}{|c|}{ Inhalation rate $(\operatorname{lnhR} ; \mathrm{m} 3 / \mathrm{d})$} & 79 & \multirow{2}{*}{\multicolumn{2}{|c|}{$\begin{array}{l}\text { Inhalation rate }(\operatorname{lnhR} ; \mathrm{m} 3 / \mathrm{d}) \\
\text { Exposure Factor }(\mathrm{m} 3 / \mathrm{kg} \bullet \mathrm{d})=\end{array}$}} & \multirow{3}{*}{$\begin{array}{r}79 \\
2.58 \mathrm{E}-01 \\
\end{array}$} & & \\
\hline & & & & \multicolumn{2}{|c|}{$\| \begin{array}{l}\text { Inhalation rate }(\operatorname{lnh} R ; \mathrm{m} 3 / \mathrm{d}) \\
\text { Exposure Factor }(\mathrm{m} 3 / \mathrm{kg} \bullet \mathrm{d})=\end{array}$} & $7.38 \mathrm{E}-03$ & & & & & & & \\
\hline & & & & $\mid \begin{array}{l}\mid \text { Contribution to } \\
\text { Contion }\end{array}$ & & & & & & & & & \\
\hline & & & & \begin{tabular}{|l} 
CANCER RISK \\
\end{tabular} & & & & & & & & & \\
\hline & $95 \%$ UCL of & PEF & Air & EXPOSURE & & & Contribution to & & & & & & \\
\hline & measured soil & or & concentration & (minus background & Cancer slope & & HAZARD & & & Air & & & \\
\hline Material present in soil at & concentration & VF & $(\mathrm{mg} / \mathrm{kg} / \mathrm{PEF})$ & for metals) & factor & Carcinogenic & EXPOSURE & Reference dose & Hazard index & \begin{tabular}{||l|} 
Concentration \\
\end{tabular} & 1-h acute REL & Concentration & \\
\hline Area 514 & $(\mathrm{mg} / \mathrm{kg})$ & $(\mathrm{m} 3 / \mathrm{kg})$ & $(\mathrm{mg} / \mathrm{m} 3)$ & $(\mathrm{mg} / \mathrm{kg} \bullet \mathrm{d})$ & Risk/(mg/kg・d) & Risk & at B514(mg/kg・d $)$ & $(\mathrm{mg} / \mathrm{kg} \bullet \mathrm{d})$ & Exposure/Rfd & $(\mu \mathrm{g} / \mathrm{m} 3)$ & $(\mu \mathrm{g} / \mathrm{m} 3)$ & to REL ratio & \\
\hline Aroclor 1242 & 0.058 & $5.21 \mathrm{E}+05$ & $1.12 \mathrm{E}-07$ & $8.25 \mathrm{E}-10$ & $2.00 \mathrm{E}+00$ & $1.65 \mathrm{E}-09$ & $2.89 \mathrm{E}-08$ & None & None & $1.12 \mathrm{E}-04$ & None & None & \\
\hline Aroclor 1254 & 0.019 & $5.21 \mathrm{E}+05$ & $3.72 \mathrm{E}-08$ & $2.74 \mathrm{E}-10$ & $2.00 \mathrm{E}+00$ & $5.49 \mathrm{E}-10$ & $9.61 \mathrm{E}-09$ & None & None & $3.72 \mathrm{E}-05$ & None & None & \\
\hline Aroclor 1260 & 0.049 & $5.21 \mathrm{E}+05$ & $9.42 \mathrm{E}-08$ & $6.95 \mathrm{E}-10$ & $2.00 E+00$ & $1.39 \mathrm{E}-09$ & $2.43 \mathrm{E}-08$ & None & None & $9.42 \mathrm{E}-05$ & None & None & \\
\hline benzene & 0.00023 & $4.15 \mathrm{E}+03$ & $5.54 \mathrm{E}-08$ & $4.09 \mathrm{E}-10$ & $1.00 \mathrm{E}-01$ & $4.09 \mathrm{E}-11$ & $\frac{1.43 \mathrm{E}-08}{1.48}$ & $1.70 \mathrm{E}-02$ & $8.42 \mathrm{E}-07$ & $5.54 \mathrm{E}-05$ & $1.30 \mathrm{E}+03$ & $4.26 \mathrm{E}-08$ & \\
\hline beryllium & 0.36 & $1.32 \mathrm{E}+09$ & $2.73 \mathrm{E}-10$ & $2.01 \mathrm{E}-12$ & $8.40 E+00$ & $1.69 \mathrm{E}-11$ & $7.05 \mathrm{E}-11$ & $2.00 \mathrm{E}-06$ & $3.52 \mathrm{E}-05$ & $2.73 \mathrm{E}-07$ & None & None & \\
\hline bis-2-ethylhexyl phthlate & 0.082 & $1.89 \mathrm{E}+07$ & $4.35 \mathrm{E}-09$ & $3.21 \mathrm{E}-11$ & $8.40 \mathrm{E}-03$ & $2.70 \mathrm{E}-13$ & $1.12 \mathrm{E}-09$ & None & None & $4.35 \mathrm{E}-06$ & None & None & \\
\hline bromomethane & 0.001 & $1.95 \mathrm{E}+03$ & $5.11 \mathrm{E}-07$ & $3.77 \mathrm{E}-09$ & None & None & $1.32 \mathrm{E}-07$ & $5.00 \mathrm{E}-03$ & $2.64 \mathrm{E}-05$ & $5.11 \mathrm{E}-04$ & $3.90 \mathrm{E}+03$ & $1.31 \mathrm{E}-07$ & \\
\hline carbon tetrachloride & 0.00015 & $1.44 \mathrm{E}+03$ & $1.04 \mathrm{E}-07$ & $7.69 \mathrm{E}-10$ & $1.50 \mathrm{E}-01$ & $1.15 \mathrm{E}-10$ & $2.69 \mathrm{E}-08$ & $1.10 \mathrm{E}-02$ & $2.45 \mathrm{E}-06$ & $1.04 \mathrm{E}-04$ & $1.90 \mathrm{E}+03$ & $5.48 \mathrm{E}-08$ & \\
\hline chloroform & 0.00016 & $2.56 \mathrm{E}+03$ & $6.05 \mathrm{E}-08$ & 4.46E-10 & $1.90 \mathrm{E}-02$ & $8.48 \mathrm{E}-12$ & $1.56 \mathrm{E}-08$ & $8.60 \mathrm{E}-02$ & $1.82 \mathrm{E}-07$ & $6.05 \mathrm{E}-05$ & $1.50 \mathrm{E}+02$ & $4.03 \mathrm{E}-07$ & \\
\hline chloromethane & 0.00027 & $1.30 \mathrm{E}+03$ & $2.08 \mathrm{E}-07$ & $1.53 \mathrm{E}-09$ & $6.30 \mathrm{E}-03$ & $9.67 \mathrm{E}-12$ & $5.37 \mathrm{E}-08$ & $2.80 \mathrm{E}-01$ & $1.92 \mathrm{E}-07$ & $2.08 \mathrm{E}-04$ & None & None & \\
\hline chromium (total) (used chromium III & 34.5 & $1.32 \mathrm{E}+09$ & $2.61 \mathrm{E}-08$ & $1.93 \mathrm{E}-10$ & None & None & & None & None & $2.61 \mathrm{E}-05$ & None & None & \\
\hline chromium, hexavalent & 0.325 & $1.32 \mathrm{E}+09$ & $2.46 \mathrm{E}-10$ & $1.82 \mathrm{E}-12$ & $5.10 \mathrm{E}+02$ & $9.27 \mathrm{E}-10$ & $6.36 \mathrm{E}-11$ & $5.70 \mathrm{E}-05$ & $1.12 \mathrm{E}-06$ & $2.46 \mathrm{E}-07$ & None & None & \\
\hline cobalt & 39.50 & $1.32 \mathrm{E}+09$ & $2.99 \mathrm{E}-08$ & $2.21 \mathrm{E}-10$ & $9.80 \mathrm{E}+00$ & $2.16 \mathrm{E}-09$ & $7.73 \mathrm{E}-09$ & $5.70 \mathrm{E}-06$ & $1.36 \mathrm{E}-03$ & $2.99 \mathrm{E}-05$ & None & None & \\
\hline copper & 27.5 & $1.32 \mathrm{E}+09$ & $2.08 \mathrm{E}-08$ & $1.54 \mathrm{E}-10$ & None & None & $5.38 \mathrm{E}-09$ & None & None & $2.08 \mathrm{E}-05$ & $1.00 \mathrm{E}+02$ & $2.08 \mathrm{E}-07$ & \\
\hline dibutyl phthlate & 0.088 & $7.97 \mathrm{E}+05$ & $1.10 \mathrm{E}-07$ & $8.10 \mathrm{E}-10$ & None & None & $2.84 \mathrm{E}-08$ & None & None & $1.10 \mathrm{E}-04$ & None & None & \\
\hline mercury & 0.11 & $1.32 \mathrm{E}+09$ & $8.32 \mathrm{E}-11$ & $6.14 \mathrm{E}-13$ & None & None & $2.15 \mathrm{E}-11$ & $2.60 \mathrm{E}-05$ & $8.26 \mathrm{E}-07$ & $8.32 \mathrm{E}-08$ & $1.80 \mathrm{E}+00$ & $4.62 \mathrm{E}-08$ & \\
\hline methylene chloride & 0.005 & $2.46 \mathrm{E}+03$ & $2.14 \mathrm{E}-06$ & $1.58 \mathrm{E}-08$ & $3.50 \mathrm{E}-03$ & $5.53 \mathrm{E}-11$ & $5.53 \mathrm{E}-07$ & $4.00 \mathrm{E}-01$ & $1.38 \mathrm{E}-06$ & $2.14 \mathrm{E}-03$ & $1.40 \mathrm{E}+04$ & None & \\
\hline methyl ethyl ketone & 0.0047 & $1.40 \mathrm{E}+04$ & $3.35 \mathrm{E}-07$ & & None & None & $8.66 \mathrm{E}-08$ & $1.40 \mathrm{E}+00$ & $6.19 \mathrm{E}-08$ & $3.35 \mathrm{E}-04$ & $1.30 \mathrm{E}+04$ & $2.58 \mathrm{E}-08$ & \\
\hline methyl isobutyl ketone & 0.0065 & $1.09 \mathrm{E}+04$ & $5.92 \mathrm{E}-07$ & & None & None & & $8.60 \mathrm{E}-01$ & $1.78 \mathrm{E}-07$ & $5.92 \mathrm{E}-04$ & None & None & \\
\hline nickel & 48.3 & $1.32 \mathrm{E}+09$ & $3.66 \mathrm{E}-08$ & $2.70 \mathrm{E}-10$ & $9.10 \mathrm{E}-01$ & $2.46 \mathrm{E}-10$ & $9.45 \mathrm{E}-09$ & $1.40 \mathrm{E}-05$ & $6.75 \mathrm{E}-04$ & $3.66 \mathrm{E}-05$ & $6.00 \mathrm{E}+00$ & $6.10 \mathrm{E}-06$ & \\
\hline petroleum hydrocarbons as diesel & & & & & 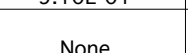 & Lator 10 & & 2 g0E-01 & $162 \mathrm{E}-02$ & & & & \\
\hline $\begin{array}{l}(\mathrm{c} 9-\mathrm{c} 18 \text { a } \\
\text { silver }\end{array}$ & $\frac{142}{1.2}$ & $\begin{array}{l}7.80 \mathrm{E}+03 \\
1.32 \mathrm{E}+09\end{array}$ & $\begin{array}{l}1.82 \mathrm{E}-02 \\
9.35 \mathrm{E}-10\end{array}$ & & None & None & & $\frac{2.90 \mathrm{E}-01}{\text { None }}$ & $\begin{array}{l}.6 \angle \mathrm{E}-02 \\
\text { None }\end{array}$ & $\frac{1.8}{9.3}$ & $\begin{array}{l}2.00 E+01 \\
\text { None }\end{array}$ & $\begin{array}{l}.08 \mathrm{E}-01 \\
\text { None }\end{array}$ & \\
\hline tetrachloroethylene (PCE) & 0.010 & $2.26 \mathrm{E}+03$ & $4.47 \mathrm{E}-06$ & 3.30 & $2.10 \mathrm{E}-02$ & $6.92 \mathrm{E}-10$ & $1.15 \mathrm{E}$ & $1.00 \mathrm{E}-02$ & $1.15 \mathrm{E}-04$ & $4.47 \mathrm{E}-03$ & $2.00 \mathrm{E}+04$ & $2.23 \mathrm{E}-07$ & \\
\hline toluene & 0.00081 & $4.75 \mathrm{E}+03$ & $1.71 \mathrm{E}-07$ & $1.26 \mathrm{E}-09$ & None & None & $4.40 \mathrm{E}-08$ & $8.60 \mathrm{E}-02$ & $5.12 \mathrm{E}-07$ & $1.71 \mathrm{E}-04$ & $3.70 \mathrm{E}+04$ & $4.61 \mathrm{E}-09$ & \\
\hline trichloroethane $1,1,1$ - & 0.0007 & $1.70 \mathrm{E}+03$ & $3.84 \mathrm{E}-07$ & $2.84 \mathrm{E}-09$ & None & None & 9.9 & $6.30 \mathrm{E}-01$ & $1.58 \mathrm{E}-07$ & $3.84 \mathrm{E}-04$ & $6.80 \mathrm{E}+04$ & $5.65 \mathrm{E}-09$ & \\
\hline trichloroethylene (TCE) & 0.037 & $2.35 \mathrm{E}+03$ & $1.55 \mathrm{E}-05$ & $1.15 \mathrm{E}-07$ & $7.00 \mathrm{E}-03$ & $8.02 \mathrm{E}-10$ & & $1.70 \mathrm{E}-02$ & $2.36 \mathrm{E}-04$ & $1.55 \mathrm{E}-02$ & None & None & \\
\hline vanadium & 34.4 & $1.32 \mathrm{E}+09$ & $2.61 \mathrm{E}-08$ & $1.92 \mathrm{E}-10$ & None & None & $6.73 \mathrm{E}-09$ & None & None & $2.61 \mathrm{E}-05$ & $3.00 \mathrm{E}+01$ & $8.69 \mathrm{E}-07$ & \\
\hline xylenes & 0.0021 & $6.63 \mathrm{E}+03$ & $3.15 \mathrm{E}-07$ & $2.33 \mathrm{E}-09$ & None & None & $8.14 \mathrm{E}-08$ & $2.00 \mathrm{E}-01$ & 4.07E-07 & $3.15 \mathrm{E}-04$ & $2.20 \mathrm{E}+04$ & $1.43 \mathrm{E}-08$ & \\
\hline zinc & 64.2 & $1.32 \mathrm{E}+09$ & $4.86 \mathrm{E}-08$ & $3.59 \mathrm{E}-10$ & None & None & $1.26 \mathrm{E}-08$ & None & None & $4.86 \mathrm{E}-05$ & None & None & \\
\hline & & & & & Risk $\sum=$ & $8.67 \mathrm{E}-09$ & & Hazard $\sum=$ & $1.86 \mathrm{E}-02$ & & Acute Hazard $\sum=$ & $9.08 \mathrm{E}-01$ & \\
\hline
\end{tabular}




\section{Attachment C (continued)}

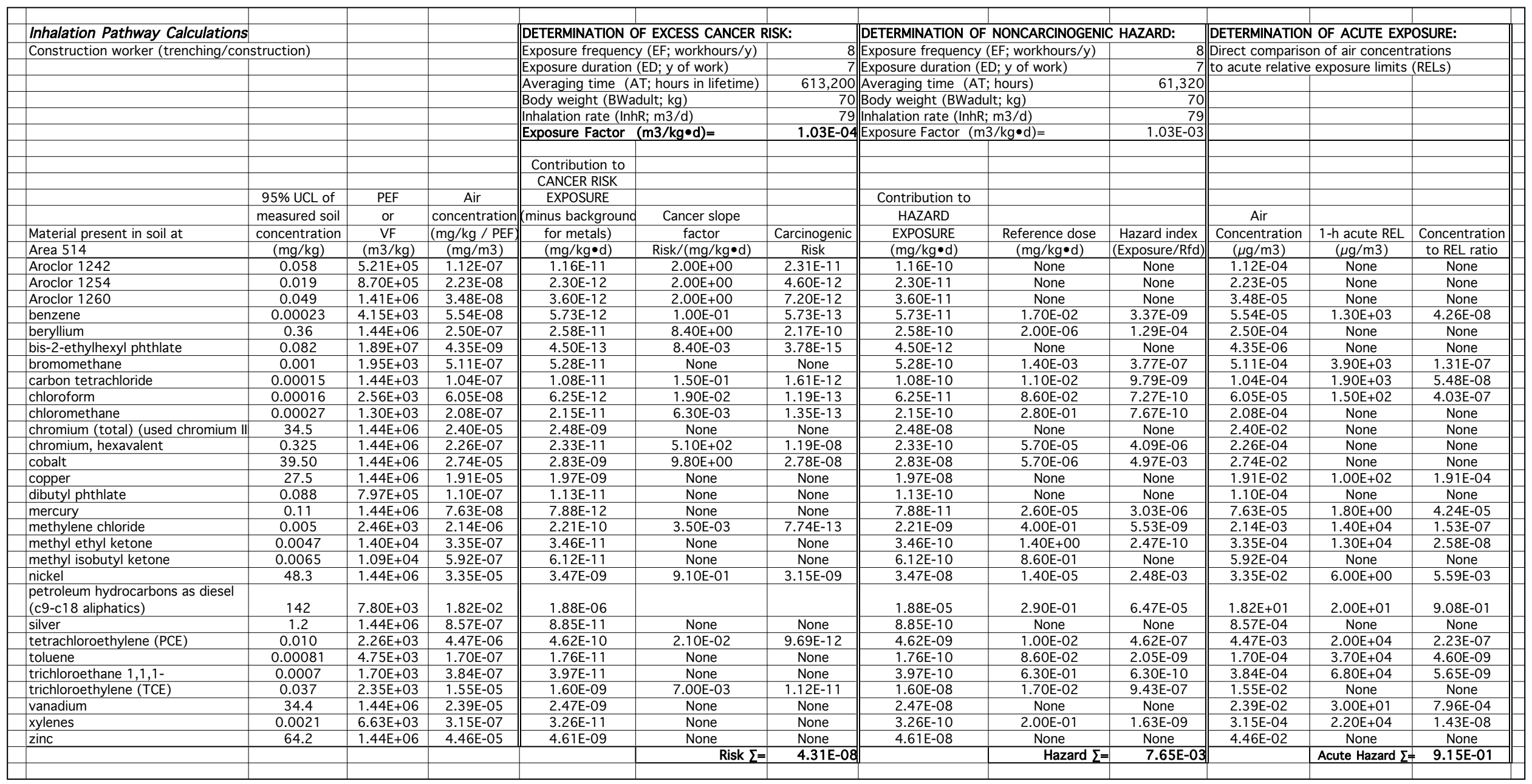




\begin{tabular}{|c|c|c|c|c|c|c|c|c|}
\hline & & & & & & & & \\
\hline Ingestion Pathway Calculations & & \multicolumn{3}{|c|}{\begin{tabular}{|l} 
DETERMINATION OF EXCESS CANCER RISK: \\
\end{tabular}} & \multicolumn{4}{|c|}{ DETERMINATION OF NONCARCINOGENIC HAZARD: } \\
\hline \multicolumn{2}{|c|}{ Construction worker (trenching/construction) } & \multirow{2}{*}{\multicolumn{2}{|c|}{\begin{tabular}{|l} 
Exposure frequency (EF; workhours/y) \\
Exposure duration (ED; y of work)
\end{tabular}}} & & \multirow{2}{*}{\multicolumn{2}{|c|}{8 Exposure frequency (EF; workhours/y) }} & \multirow{2}{*}{\multicolumn{2}{|c|}{$\frac{8}{7}$}} \\
\hline & & & & & & & & \\
\hline & & \multicolumn{2}{|c|}{ Averaging time (AT; hours in lifetime) } & 613,200 & \multicolumn{2}{|c|}{ Averaging time (AT; hours) } & 61,320 & \\
\hline & & \multicolumn{2}{|c|}{ Body weight (BWadult; kg) } & 70 & \multicolumn{2}{|c|}{ Body weight (BWadult; kg) } & 70 & \\
\hline & & \multicolumn{2}{|c|}{ Soil ingestion rate (IRadult; kg/d) } & 0.0001 & \multicolumn{2}{|c|}{ Soil ingestion rate (IRadult; $\mathrm{kg} / \mathrm{d}$ ) } & 0.0001 & \\
\hline & & \multicolumn{2}{|c|}{ Exposure Factor $(\mathrm{kg} / \mathrm{kg} \bullet \mathrm{d})=$} & $1.30 \mathrm{E}-10$ & \multicolumn{2}{|c|}{ Exposure Factor $(\mathrm{kg} / \mathrm{kg} \bullet \mathrm{d})=$} & $1.30 \mathrm{E}-09$ & \\
\hline & & & & & & & & \\
\hline & & Contribution to & & & & & & \\
\hline & & CANCER RISK & & & & & & \\
\hline & $95 \%$ UCL of & EXPOSURE & & & Contribution to & & & \\
\hline & measured soil & (minus background & Cancer slope & & HAZARD & Reference & & \\
\hline Material present in soil at & concentration & for metals) & factor oral & Carcinogenic & EXPOSURE & oral dose & Hazard index & \\
\hline Area 514 & $(\mathrm{mg} / \mathrm{kg})$ & $(\mathrm{mg} / \mathrm{kg} \bullet \mathrm{d})$ & Risk $/(\mathrm{mg} / \mathrm{kg} \bullet \mathrm{d})$ & Risk & $(\mathrm{mg} / \mathrm{kg} \bullet \mathrm{d})$ & $(\mathrm{mg} / \mathrm{kg} \bullet \mathrm{d})$ & (Exposure/Rfd) & \\
\hline Aroclor 1242 & 0.058 & $7.60 \mathrm{E}-12$ & $5.00 \mathrm{E}+00$ & $3.80 \mathrm{E}-11$ & $7.60 \mathrm{E}-11$ & $2.00 \mathrm{E}-05$ & $3.80 \mathrm{E}-06$ & \\
\hline Aroclor 1254 & 0.019 & $2.53 \mathrm{E}-12$ & $5.00 \mathrm{E}+00$ & $1.26 \mathrm{E}-11$ & $2.53 \mathrm{E}-11$ & $2.00 \mathrm{E}-05$ & $1.26 \mathrm{E}-06$ & \\
\hline Aroclor 1260 & 0.049 & $6.40 \mathrm{E}-12$ & $5.00 \mathrm{E}+00$ & $3.20 \mathrm{E}-11$ & $6.40 \mathrm{E}-11$ & $2.00 \mathrm{E}-05$ & $3.20 \mathrm{E}-06$ & \\
\hline benzene & 0.00023 & $3.00 \mathrm{E}-14$ & $1.00 \mathrm{E}-01$ & $3.00 \mathrm{E}-15$ & $3.00 \mathrm{E}-13$ & $4.00 \mathrm{E}-03$ & $7.50 \mathrm{E}-11$ & \\
\hline beryllium & 0.36 & $4.70 \mathrm{E}-11$ & $4.30 \mathrm{E}+00$ & $2.02 \mathrm{E}-10$ & $4.70 \mathrm{E}-10$ & $2.00 \mathrm{E}-03$ & $2.35 \mathrm{E}-07$ & \\
\hline bis-2-ethylhexyl phthlate & 0.082 & $1.07 \mathrm{E}-11$ & $3.00 \mathrm{E}-03$ & $3.21 \mathrm{E}-14$ & $1.07 \mathrm{E}-10$ & $2.00 \mathrm{E}-02$ & $5.36 \mathrm{E}-09$ & \\
\hline bromomethane & 0.001 & $1.30 \mathrm{E}-13$ & None & None & $1.30 \mathrm{E}-12$ & $1.40 \mathrm{E}-03$ & $9.29 \mathrm{E}-10$ & \\
\hline carbon tetrachloride & 0.00015 & $1.96 \mathrm{E}-14$ & $1.50 \mathrm{E}-01$ & $2.94 \mathrm{E}-15$ & $1.96 \mathrm{E}-13$ & $7.00 \mathrm{E}-04$ & $2.80 \mathrm{E}-10$ & \\
\hline chloroform & 0.00016 & $2.02 \mathrm{E}-14$ & $3.10 \mathrm{E}-02$ & $6.27 \mathrm{E}-16$ & $2.02 \mathrm{E}-13$ & 1.00E-02 & $2.02 \mathrm{E}-11$ & \\
\hline chloromethane & 0.00027 & $3.52 \mathrm{E}-14$ & $1.30 \mathrm{E}-02$ & $4.58 \mathrm{E}-16$ & $3.52 \mathrm{E}-13$ & None & None & \\
\hline chromium (total) (used chromium III & 34.5 & $4.50 \mathrm{E}-09$ & None & None & $4.50 \mathrm{E}-08$ & $1.50 \mathrm{E}+00$ & $3.00 \mathrm{E}-08$ & \\
\hline chromium, hexavalent & 0.325 & $4.24 \mathrm{E}-11$ & None & None & $4.24 \mathrm{E}-10$ & $3.00 \mathrm{E}-03$ & $1.41 \mathrm{E}-07$ & \\
\hline cobalt & 39.50 & $5.15 \mathrm{E}-09$ & None & None & $5.15 \mathrm{E}-08$ & $2.00 \mathrm{E}-02$ & $2.58 \mathrm{E}-06$ & \\
\hline copper & 27.5 & $3.59 \mathrm{E}-09$ & None & None & $3.59 \mathrm{E}-08$ & $4.00 \mathrm{E}-02$ & 8.97E-07 & \\
\hline dibutyl phthlate & 0.088 & $1.14 \mathrm{E}-11$ & None & None & $1.14 \mathrm{E}-10$ & $1.00 \mathrm{E}-01$ & $1.14 \mathrm{E}-09$ & \\
\hline mercury & 0.11 & $1.43 \mathrm{E}-11$ & None & None & $1.43 \mathrm{E}-10$ & $3.00 \mathrm{E}-03$ & $4.77 \mathrm{E}-08$ & \\
\hline methylene chloride & 0.005 & $6.86 \mathrm{E}-13$ & $1.40 \mathrm{E}-02$ & $9.60 \mathrm{E}-15$ & $6.86 \mathrm{E}-12$ & $6.00 \mathrm{E}-02$ & $1.14 \mathrm{E}-10$ & \\
\hline methyl ethyl ketone & 0.0047 & $6.14 \mathrm{E}-13$ & None & None & $6.14 \mathrm{E}-12$ & $6.00 \mathrm{E}-01$ & $1.02 \mathrm{E}-11$ & \\
\hline methyl isobutyl ketone & 0.0065 & $8.42 \mathrm{E}-13$ & None & None & $8.42 \mathrm{E}-12$ & 8.00E-02 & $1.05 \mathrm{E}-10$ & \\
\hline nickel & 48.3 & 6.30E-09 & None & None & $6.30 \mathrm{E}-08$ & $2.00 \mathrm{E}-02$ & $3.15 \mathrm{E}-06$ & \\
\hline $\begin{array}{l}\text { petroleum hydrocarbons as diesel } \\
\text { (c9-c18 aliphatics) }\end{array}$ & 142 & $1.85 \mathrm{E}-08$ & None & None & $1.85 \mathrm{E}-07$ & $1.00 \mathrm{E}-01$ & $1.85 \mathrm{E}-06$ & \\
\hline silver & 1.2 & $1.61 \mathrm{E}-10$ & None & None & $1.61 \mathrm{E}-09$ & $5.00 \mathrm{E}-03$ & $3.22 \mathrm{E}-07$ & \\
\hline tetrachloroethylene (PCE) & 0.010 & $1.32 \mathrm{E}-12$ & $5.40 \mathrm{E}-01$ & $7.10 \mathrm{E}-13$ & $1.32 \mathrm{E}-11$ & $1.00 \mathrm{E}-02$ & $1.32 \mathrm{E}-09$ & \\
\hline toluene & 0.00081 & $1.06 \mathrm{E}-13$ & None & None & $1.06 \mathrm{E}-12$ & $2.00 \mathrm{E}-01$ & $5.28 \mathrm{E}-12$ & \\
\hline trichloroethane $1,1,1-$ & 0.0007 & $8.52 \mathrm{E}-14$ & None & None & $8.52 \mathrm{E}-13$ & $2.00 \mathrm{E}-01$ & $4.26 \mathrm{E}-12$ & \\
\hline trichloroethylene (TCE) & 0.037 & $4.76 \mathrm{E}-12$ & $1.30 \mathrm{E}-02$ & $6.19 \mathrm{E}-14$ & $4.76 \mathrm{E}-11$ & $3.00 \mathrm{E}-04$ & $1.59 \mathrm{E}-07$ & \\
\hline vanadium & 34.4 & $4.49 \mathrm{E}-09$ & None & None & $4.49 \mathrm{E}-08$ & 7.00E-03 & $6.41 \mathrm{E}-06$ & \\
\hline xylenes & 0.0021 & $2.73 \mathrm{E}-13$ & None & None & $2.73 \mathrm{E}-12$ & 2.00E-01 & $1.36 \mathrm{E}-11$ & \\
\hline zinc & 64.2 & $8.38 \mathrm{E}-09$ & None & None & $8.38 \mathrm{E}-08$ & $3.00 \mathrm{E}-01$ & $2.79 \mathrm{E}-07$ & \\
\hline & & & Risk $\sum=$ & $2.85 \mathrm{E}-10$ & & Hazard $\sum=$ & $2.44 \mathrm{E}-05$ & \\
\hline & & & & & & & & \\
\hline
\end{tabular}




\section{Attachment C (continued)}

\begin{tabular}{|c|c|c|c|c|c|c|c|c|}
\hline & & & & & & & & \\
\hline Dermal Absorption Pathway Calcu & ulations & & FOR DETERMINATION OF & ESS CANCER RISK: & & FOR DETERMINATION OF NONCA & RCINOGENIC HAZA & RD: \\
\hline Construction worker (trenching/const & truction) & & Exposure frequency (EF; $w$ & ours/y) & 8 & Exposure frequency (EF; workhour & $s / y)$ & 8 \\
\hline & & & Exposure duration (ED; yo & ork) & 7 & Exposure duration (ED; y of work) & & \\
\hline & & & Averaging time (AT; hour & lifetime) & 613,200 & Averaging time (AT; hours ) & & 61,320 \\
\hline & & & Body weight (BWadult; $\mathrm{kg}$ & & 70 & Body weight (BWadult; kg) & & 70 \\
\hline & & & Soil adherence factor (mg & & 0.24 & Soil adherence factor $(\mathrm{mg} / \mathrm{cm} 2)$ & & 0.24 \\
\hline & & & Skin surface area exposure & e (SSAadult; cm2/d) & 5,800 & Skin surface area exposure rate $(S$ & SAadult; cm2/d) & 5,800 \\
\hline & & & Unit conversion $(10-6 \mathrm{~kg}$ & & $1 . \mathrm{E}-06$ & Unit conversion $(10-6 \mathrm{~kg} / \mathrm{mg})$ & & $1 . \mathrm{E}-06$ \\
\hline & & & Exposure Factor $(d-1)=$ & & $1.82 \mathrm{E}-09$ & Exposure Factor $(d-1)=$ & & $1.82 \mathrm{E}-08$ \\
\hline & & & & & & & & \\
\hline & & & Contribution to & & & & & \\
\hline & & & CANCER RISK & & & & & \\
\hline & $95 \%$ UCL of & & EXPOSURE & & & Contribution to & & \\
\hline & measured soil & & (minus background & Cancer slope & & HAZARD & Reference & \\
\hline Material present in soil at & \begin{tabular}{|l|} 
concentration \\
\end{tabular} & Absorption & for metals) & factor--dermal & Carcinogenic & EXPOSURE & dermal dose & Hazard index \\
\hline Area 514 & $(\mathrm{mg} / \mathrm{kg})$ & fraction & $(\mathrm{mg} / \mathrm{kg} \bullet \mathrm{d})$ & Risk $/(\mathrm{mg} / \mathrm{kg} \bullet \mathrm{d})$ & Risk & $(\mathrm{mg} / \mathrm{kg} \bullet \mathrm{d})$ & $(\mathrm{mg} / \mathrm{kg} \bullet \mathrm{d})$ & (Exposure/Rfd) \\
\hline Aroclor 1242 & 0.058 & $1.40 \mathrm{E}-01$ & $1.48 \mathrm{E}-11$ & $5.00 \mathrm{E}+00$ & $7.41 \mathrm{E}-11$ & $1.48 \mathrm{E}-10$ & $2.00 \mathrm{E}-05$ & $7.41 \mathrm{E}-06$ \\
\hline Aroclor 1254 & 0.019 & $1.40 \mathrm{E}-01$ & $4.93 \mathrm{E}-12$ & $5.00 \mathrm{E}+00$ & $2.46 \mathrm{E}-11$ & $4.93 \mathrm{E}-11$ & $2.00 \mathrm{E}-05$ & $2.46 \mathrm{E}-06$ \\
\hline Aroclor 1260 & 0.049 & $1.40 \mathrm{E}-01$ & $1.25 \mathrm{E}-11$ & $5.00 \mathrm{E}+00$ & $6.24 \mathrm{E}-11$ & $1.25 \mathrm{E}-10$ & $2.00 \mathrm{E}-05$ & $6.24 \mathrm{E}-06$ \\
\hline benzene & 0.00023 & $1.00 \mathrm{E}-02$ & $4.18 \mathrm{E}-15$ & $1.00 \mathrm{E}-01$ & $4.18 \mathrm{E}-16$ & $4.18 \mathrm{E}-14$ & $4.00 \mathrm{E}-03$ & $1.04 \mathrm{E}-11$ \\
\hline beryllium & 0.36 & $1.00 \mathrm{E}-03$ & $6.54 \mathrm{E}-13$ & $4.30 \mathrm{E}+00$ & $2.81 \mathrm{E}-12$ & $6.54 \mathrm{E}-12$ & $2.00 \mathrm{E}-03$ & $3.27 \mathrm{E}-09$ \\
\hline bis-2-ethylhexyl phthlate & 0.082 & $1.00 \mathrm{E}-02$ & $1.49 \mathrm{E}-12$ & $2.00 \mathrm{E}-02$ & $2.98 \mathrm{E}-14$ & $1.49 \mathrm{E}-11$ & $2.00 \mathrm{E}-02$ & $7.45 \mathrm{E}-10$ \\
\hline bromomethane & 0.001 & $1.00 \mathrm{E}-02$ & $1.81 \mathrm{E}-14$ & $1.40 \mathrm{E}-03$ & $2.53 \mathrm{E}-17$ & $1.81 \mathrm{E}-13$ & $1.40 \mathrm{E}-03$ & $1.29 \mathrm{E}-10$ \\
\hline carbon tetrachloride & 0.00015 & $1.00 \mathrm{E}-02$ & $2.72 \mathrm{E}-15$ & $1.50 \mathrm{E}-01$ & $4.09 \mathrm{E}-16$ & $2.72 \mathrm{E}-14$ & $7.00 \mathrm{E}-04$ & $3.89 \mathrm{E}-11$ \\
\hline chloroform & 0.00016 & $1.00 \mathrm{E}-02$ & $2.81 \mathrm{E}-15$ & $3.10 \mathrm{E}-02$ & $8.73 \mathrm{E}-17$ & $2.81 \mathrm{E}-14$ & $1.00 \mathrm{E}-02$ & $2.81 \mathrm{E}-12$ \\
\hline chloromethane & 0.00027 & $1.00 \mathrm{E}-02$ & $4.90 \mathrm{E}-15$ & $1.30 \mathrm{E}-02$ & $6.37 \mathrm{E}-17$ & $4.90 \mathrm{E}-14$ & None & None \\
\hline chromium, hexavalent & 0.325 & $1.00 \mathrm{E}-03$ & $5.90 \mathrm{E}-13$ & None & None & $5.90 \mathrm{E}-12$ & $1.50 \mathrm{E}+00$ & $3.93 \mathrm{E}-12$ \\
\hline chromium (total) (used chromium III) & 34.5 & $1.00 \mathrm{E}-03$ & $6.27 \mathrm{E}-11$ & None & None & $6.27 \mathrm{E}-10$ & $3.00 \mathrm{E}-03$ & $2.09 \mathrm{E}-07$ \\
\hline cobalt & 39.50 & $1.00 \mathrm{E}-03$ & $7.17 \mathrm{E}-11$ & None & None & $7.17 \mathrm{E}-10$ & $2.00 \mathrm{E}-02$ & $3.59 \mathrm{E}-08$ \\
\hline copper & 27.5 & $1.00 \mathrm{E}-03$ & $4.99 \mathrm{E}-11$ & None & None & $4.99 \mathrm{E}-10$ & $4.00 \mathrm{E}-02$ & $1.25 \mathrm{E}-08$ \\
\hline dibutyl phthlate & 0.088 & $1.00 \mathrm{E}-02$ & $1.59 \mathrm{E}-12$ & None & None & $1.59 \mathrm{E}-11$ & $1.00 \mathrm{E}-01$ & $1.59 \mathrm{E}-10$ \\
\hline mercury & 0.11 & $1.00 \mathrm{E}-03$ & $1.99 \mathrm{E}-13$ & None & None & $1.99 \mathrm{E}-12$ & $3.00 \mathrm{E}-03$ & $6.65 \mathrm{E}-10$ \\
\hline methylene chloride & 0.005 & $1.00 \mathrm{E}-02$ & $9.54 \mathrm{E}-14$ & $1.40 \mathrm{E}-02$ & $1.34 \mathrm{E}-15$ & $9.54 \mathrm{E}-13$ & $6.00 \mathrm{E}-02$ & $1.59 \mathrm{E}-11$ \\
\hline methyl ethyl ketone & 0.0047 & $1.00 \mathrm{E}-02$ & $8.55 \mathrm{E}-14$ & None & None & $8.55 \mathrm{E}-13$ & $6.00 \mathrm{E}-01$ & $1.43 \mathrm{E}-12$ \\
\hline methyl isobutyl ketone & 0.0065 & $1.00 \mathrm{E}-02$ & $1.17 \mathrm{E}-13$ & None & None & $1.17 \mathrm{E}-12$ & $8.00 \mathrm{E}-02$ & $1.46 \mathrm{E}-11$ \\
\hline nickel & 48.3 & $1.00 \mathrm{E}-03$ & $8.77 \mathrm{E}-11$ & None & None & $8.77 \mathrm{E}-10$ & $2.00 \mathrm{E}-02$ & $4.39 \mathrm{E}-08$ \\
\hline petroleum hydrocarbons as diesel & & & & & & & & \\
\hline (c9-c18 aliphatics) & 142 & $1.00 \mathrm{E}-02$ & 2.57E-09 & None & None & 2.57E-08 & 1.00E-01 & 2.57E-07 \\
\hline silver & 1.2 & $1.00 \mathrm{E}-03$ & $2.24 \mathrm{E}-12$ & None & None & $2.24 \mathrm{E}-11$ & $5.00 \mathrm{E}-03$ & $4.48 \mathrm{E}-09$ \\
\hline tetrachloroethylene (PCE) & 0.010 & $1.00 \mathrm{E}-02$ & $1.83 \mathrm{E}-13$ & $5.40 \mathrm{E}-01$ & $9.89 \mathrm{E}-14$ & $1.83 \mathrm{E}-12$ & $1.00 \mathrm{E}-02$ & $1.83 \mathrm{E}-10$ \\
\hline toluene & 0.00081 & $1.00 \mathrm{E}-02$ & $1.47 \mathrm{E}-14$ & None & None & $1.47 \mathrm{E}-13$ & $2.00 \mathrm{E}-01$ & $7.35 \mathrm{E}-13$ \\
\hline trichloroethylene (TCE) & 0.0007 & $1.00 \mathrm{E}-02$ & $1.19 \mathrm{E}-14$ & $1.30 \mathrm{E}-02$ & $1.54 \mathrm{E}-16$ & $1.19 \mathrm{E}-13$ & $3.00 \mathrm{E}-04$ & $3.95 \mathrm{E}-10$ \\
\hline trichloroethane 1,1,1- & 0.037 & $1.00 \mathrm{E}-02$ & $6.63 \mathrm{E}-13$ & None & None & $6.63 \mathrm{E}-12$ & $2.00 \mathrm{E}-01$ & $3.32 \mathrm{E}-11$ \\
\hline vanadium & 34.4 & $1.00 \mathrm{E}-03$ & $6.25 \mathrm{E}-11$ & None & None & $6.25 \mathrm{E}-10$ & $7.00 \mathrm{E}-03$ & $8.92 \mathrm{E}-08$ \\
\hline xylenes & 0.0021 & $1.00 \mathrm{E}-02$ & $3.80 \mathrm{E}-14$ & None & None & $3.80 \mathrm{E}-13$ & $2.00 \mathrm{E}-01$ & $1.90 \mathrm{E}-12$ \\
\hline zinc & 64.2 & $1.00 \mathrm{E}-03$ & $1.17 \mathrm{E}-10$ & None & None & $1.17 \mathrm{E}-09$ & $3.00 \mathrm{E}-01$ & $3.89 \mathrm{E}-09$ \\
\hline & & & & Risk $\sum=$ & $1.64 \mathrm{E}-10$ & & Hazard $\sum=$ & $1.68 \mathrm{E}-05$ \\
\hline & & & & & & & & \\
\hline
\end{tabular}


Attachment C (continued)

\begin{tabular}{|c|c|c|c|c|c|c|c|c|c|c|c|c|c|}
\hline Inhalation exposure & & & & & & 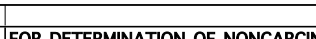 & & & & & & \\
\hline $\begin{array}{l}\text { Inhalation exposure } \\
\text { Residential Exposure }\end{array}$ & & & \multicolumn{2}{|c|}{$\begin{array}{l}\text { FOR DETERMINATION OF EXCESS CANCI } \\
\text { Exposure frequency (EF; } d / y) \text { ( }\end{array}$} & $\begin{array}{ll}\text { Adult } & \\
& 350\end{array}$ & $\frac{\text { Child }}{350}$ & \multicolumn{2}{|c|}{ Exposure frequency (EF; workhours/y) } & \begin{tabular}{l|l} 
Adult & \\
350
\end{tabular} & Child & & & \\
\hline & & & \multirow{2}{*}{\multicolumn{2}{|c|}{$\begin{array}{l}\text { Exposure duration (ED; y of residence) } \\
\text { Averaging time (AT; days in lifetime) }\end{array}$}} & 24 & & \multicolumn{2}{|l|}{ Exposure duration (ED; $y$ of residence) } & 24 & $\begin{array}{r}350 \\
6\end{array}$ & & & \\
\hline & & & & & 25,550 & 25,550 & \multicolumn{2}{|l|}{ Averaging time (AT; days in age group) } & 8,760 & \multicolumn{2}{|l|}{2,190} & & \\
\hline & & & \multicolumn{2}{|c|}{ Body weight (BW; kg) } & $\begin{array}{r}70 \\
20\end{array}$ & & \multirow{3}{*}{\multicolumn{2}{|c|}{$\begin{array}{l}\text { Inhalation rate }\left(\mathrm{mg} / \mathrm{m} / \mathrm{m}^{\wedge}-\mathrm{d}\right) \\
\text { Exposure Factor }(\mathrm{d}-1)=\end{array}$}} & 70 & 15 & & & \\
\hline & & & \multicolumn{2}{|c|}{$\begin{array}{l}\text { Inhalation rate }\left(m g / m^{\wedge} 3-d\right) \\
\text { Exposure Factor }(d-1)=\end{array}$} & 20 & $\begin{aligned} 10 \\
1.49 \mathrm{E}-01\end{aligned}$ & & & 20 & $\begin{array}{r}10 \\
9.13 \mathrm{E}-01\end{array}$ & & & \\
\hline & & & & & & & & & & & & & \\
\hline & & & & & & & & & & & & & \\
\hline & & & & & & & & & & & & & \\
\hline & Soil & $\begin{array}{l}\text { PEF } \\
\text { or }\end{array}$ & \begin{tabular}{l|} 
Air \\
concentration \\
\end{tabular} & $\begin{array}{l}\text { Contribution to } \\
\text { CANER RISK }\end{array}$ & Cancer slope & & $\begin{array}{l}95 \% \text { UCL of } \\
\text { measured soil }\end{array}$ & $\begin{array}{l}\text { PEF } \\
\text { or }\end{array}$ & \begin{tabular}{|l|} 
Air \\
concentration \\
\end{tabular} & $\begin{array}{l}\text { Contribution to } \\
\text { HAZARD }\end{array}$ & Reference & & \\
\hline Material present in soil at & concentration & VF & $\mathrm{mg} / \mathrm{kg} / \mathrm{PEF}$ & EXPOSURE & factor-inhalation & Carcinogenic & concentration & $\mathrm{VF}$ & $(\mathrm{mg} / \mathrm{kg} / \mathrm{PEF})$ & $\begin{array}{l}\text { MALARD } \\
\text { EXPOSURE }\end{array}$ & $\begin{array}{l}\text { Relerence } \\
\text { inhalation }\end{array}$ & Hazard index & \\
\hline Area 514 & $(\mathrm{mg} / \mathrm{kg})$ & $(\mathrm{m} 3 / \mathrm{kg})$ & $(\mathrm{mg} / \mathrm{m} 3)$ & at $\mathrm{B} 514(\mathrm{mg} / \mathrm{kg} \bullet \mathrm{d})$ & $\mathrm{Risk} /(\mathrm{mg} / \mathrm{kg} \bullet \mathrm{d})$ & Risk & $(\mathrm{mg} / \mathrm{kg})$ & $(\mathrm{m} 3 / \mathrm{kg})$ & $(\mathrm{mg} / \mathrm{m} 3)$ & $(\mathrm{mg} / \mathrm{kg} \bullet \mathrm{d})$ & $(\mathrm{mg} / \mathrm{kg} \bullet \mathrm{d})$ & (Exposure/Rfd) & \\
\hline Aroclor 1242 & 0.058 & $5.21 \mathrm{E}+05$ & \begin{tabular}{|l|l|}
$1.12 E-07$ \\
\end{tabular} & $\frac{1.66 \mathrm{E}-08}{108}$ & $\frac{2.00 E+00}{2.00}$ & $3.33 \mathrm{E}-08$ & 0.058 & $5.21 \mathrm{E}+05$ & $1.12 \mathrm{E}-07$ & $\frac{1.02 E-07}{1.07}$ & None & $\frac{\text { None }}{2}$ & \\
\hline Aroclor 1254 & 0.019 & $5.21 \mathrm{E}+05$ & \begin{tabular}{|c|}
$3.72 \mathrm{E}-08$ \\
\end{tabular} & $5.53 \mathrm{E}-09$ & $2.00 \mathrm{E}+00$ & $1.11 \mathrm{E}-08$ & 0.019 & $5.21 \mathrm{E}+05$ & $3.72 \mathrm{E}-08$ & $3.40 \mathrm{E}-08$ & None & None & \\
\hline Aroclor 1260 & 0.049 & $5.21 E+05$ & \begin{tabular}{|l|l|}
$9.42 \mathrm{E}-08$ \\
55.50
\end{tabular} & $1.40 \mathrm{E}-08$ & $2.00 E+00$ & $2.80 \mathrm{E}-08$ & 0.049 & $5.21 E+05$ & $9.42 \mathrm{E}-08$ & $8.60 \mathrm{E}-08$ & None & None & \\
\hline benzene & 0.00023 & $\begin{array}{l}4.15 \mathrm{E}+03 \\
1.32 \mathrm{E}+09\end{array}$ & 5.54E-08 & 8.24E-09 & $\begin{array}{l}\frac{1.00 E-01}{8.40 E+00} \\
\end{array}$ & $8.24 \mathrm{E}-10$ & 0.00023 & $4.15 E+03$ & $5.54 \mathrm{E}-08$ & $5.06 \mathrm{E}-08$ & $1.70 \mathrm{E}-02$ & $2.98 \mathrm{E}-06$ & \\
\hline beryllium & 0.082 & $\begin{array}{l}1.32 \mathrm{E}+09 \\
1.89 \mathrm{E}+07\end{array}$ & $4.35 \mathrm{E}-09$ & $6.47 \mathrm{E}-10$ & $\begin{array}{l}8.40 E+00 \\
8.40 E-03\end{array}$ & $\begin{array}{c}\text { None } \\
5.44 \mathrm{E}-12\end{array}$ & $\begin{array}{c}0.36 \\
0.082\end{array}$ & \begin{tabular}{|l|}
$1.32 E+09$ \\
$1.89 E+07$
\end{tabular} & $\begin{array}{l}2.73 \mathrm{E}-10 \\
4.35-09\end{array}$ & $\begin{array}{l}2.49 E-10 \\
3.97-09\end{array}$ & $\begin{array}{c}2.00 E-06 \\
\text { None }\end{array}$ & 1.25E-04 & \\
\hline bromomethane & 0.001 & $1.95 \mathrm{E}+03$ & \begin{tabular}{|l|}
$5.11 \mathrm{E}-07$ \\
\end{tabular} & $\begin{array}{l}0.41 \mathrm{E}-10 \\
7.60 \mathrm{E}-08 \\
\end{array}$ & None & $\begin{array}{l}\text { 5.44E-TL } \\
\text { None }\end{array}$ & 0.001 & $1.95 \mathrm{E}+03$ & $\begin{array}{l}4.35-09 \\
5.11 \mathrm{E}-07\end{array}$ & $\begin{array}{l}3.97 \mathrm{E}-09 \\
4.66 \mathrm{E}-07\end{array}$ & $\begin{array}{c}\text { None } \\
1.40 \mathrm{E}-03\end{array}$ & $\begin{array}{l}\text { None } \\
3.33 \mathrm{E}-04\end{array}$ & \\
\hline carbon tetrachloride & 0.00015 & $1.44 \mathrm{E}+03$ & \begin{tabular}{|l|}
$1.04 \mathrm{E}-07$ \\
\end{tabular} & $1.55 \mathrm{E}-08$ & $1.50 \mathrm{E}-01$ & $2.32 E-09$ & 0.00015 & $1.44 \mathrm{E}+03$ & $1.04 \mathrm{E}-07$ & $9.52 \mathrm{E}-08$ & $1.10 \mathrm{E}-02$ & $8.65 \mathrm{E}-06$ & \\
\hline chloroform & 0.00016 & $2.56 \mathrm{E}+03$ & $6.05 \mathrm{E}-08$ & $8.99 \mathrm{E}-09$ & $1.90 \mathrm{E}-02$ & $1.71 \mathrm{E}-10$ & 0.000155 & $2.56 \mathrm{E}+03$ & $6.05 E-08$ & $5.52 \mathrm{E}-08$ & $8.60 \mathrm{E}-02$ & $6.42 E-07$ & \\
\hline chloromethane & 0.00027 & $1.30 E+03$ & $2.08 \mathrm{E}-07$ & $3.09 E-08$ & $6.30 \mathrm{E}-03$ & $1.95 \mathrm{E}-10$ & 0.00027 & $1.30 \mathrm{E}+03$ & $2.08 \mathrm{E}-07$ & $1.90 \mathrm{E}-07$ & $2.80 \mathrm{E}-01$ & $6.78 \mathrm{E}-07$ & \\
\hline chromium (total) (used chromium III) & 24.9 & $1.32 E+09$ & $1.89 \mathrm{E}-08$ & $2.81 \mathrm{E}-09$ & None & None & 34.5 & $1.32 \mathrm{E}+09$ & $2.61 \mathrm{E}-08$ & $2.39 \mathrm{E}-08$ & None & None & \\
\hline \begin{tabular}{|l} 
chromium (hexavalent) \\
cobalt
\end{tabular} & $\begin{array}{l}0.325 \\
39.50\end{array}$ & $\begin{array}{l}1.32 \mathrm{E}+09 \\
1.32 \mathrm{E}+09\end{array}$ & $\left|\begin{array}{|l|}2.46 E-10 \\
2.99 E-08\end{array}\right|$ & $\begin{array}{l}3.66 \mathrm{E}-11 \\
4.45-09\end{array}$ & $\frac{5.10 \mathrm{E}+02}{9.80+00}$ & $\begin{array}{l}1.87 \mathrm{E}-08 \\
4.36 \mathrm{E}-08\end{array}$ & 0.325 & \begin{tabular}{|l|}
$1.32 E+09$ \\
$1.32 E+09$ \\
\end{tabular} & $\frac{2.46 \mathrm{E}-10}{2.99 \mathrm{E}-08}$ & $\frac{2.25 \mathrm{E}-10}{2.73 \mathrm{E}-08}$ & $\begin{array}{l}5.70 \mathrm{E}-05 \\
5.70 \mathrm{E}-06\end{array}$ & $\begin{array}{l}3.94 \mathrm{E}-06 \\
4.79 \mathrm{E}-03\end{array}$ & \\
\hline copper & $\frac{29.50}{27.5}$ & $1.32 E+09$ & $\mid$\begin{tabular}{|c|}
$2.99 \mathrm{E}-08$ \\
$2.08 \mathrm{E}-08$
\end{tabular} & $\begin{array}{l}4.45 \mathrm{E}-09 \\
.10 \mathrm{E}-09\end{array}$ & $\begin{array}{l}9.80+00 \\
\text { None }\end{array}$ & None & $\frac{99.50}{27.5}$ & \begin{tabular}{|l|}
$.32 \mathrm{E}+09$ \\
$1.32 \mathrm{E}+09$
\end{tabular} & $\begin{array}{l}2.99 \mathrm{E}-08 \\
2.08 \mathrm{E}-08\end{array}$ & $\begin{array}{l}2.73 \mathrm{E}-08 \\
1.90 \mathrm{E}-08\end{array}$ & $\frac{5.70 E-06}{\text { None }}$ & $\begin{array}{l}\text { 4. } \\
\text { None }\end{array}$ & \\
\hline dibutyl phthlate & 0.088 & $7.97 \mathrm{E}+05$ & $1.10 \mathrm{E}-07$ & $1.63 \mathrm{E}-08$ & None & None & 0.088 & $7.97 \mathrm{E}+05$ & $1.10 \mathrm{E}-07$ & $1.00 \mathrm{E}-07$ & None & None & \\
\hline mercury & 0.11 & $1.32 E+09$ & $8.32 \mathrm{E}-11$ & $1.24 \mathrm{E}-11$ & None & None & 0.1098 & $1.32 \mathrm{E}+09$ & $8.32 \mathrm{E}-11$ & $7.60 \mathrm{E}-11$ & $2.60 \mathrm{E}-05$ & $2.92 E-06$ & \\
\hline methylene chloride & 0.005 & $2.46 E+03$ & $2.14 \mathrm{E}-06$ & $3.18 \mathrm{E}-07$ & $3.50 \mathrm{E}-03$ & $1.11 \mathrm{E}-09$ & 0.005 & $2.46 \mathrm{E}+03$ & $2.14 \mathrm{E}-06$ & $1.95 \mathrm{E}-06$ & $4.00 \mathrm{E}-01$ & 4.89E-06 & \\
\hline $\begin{array}{l}\text { methyl ethyl ketone } \\
\text { methyl lisobuttyl ketong }\end{array}$ & 0.0047 & $\begin{array}{l}1.40 \mathrm{E}+04 \\
1.09 \mathrm{E}+04\end{array}$ & \begin{tabular}{|l|}
$3.35 E-07$ \\
$5.92 E-07$
\end{tabular} & $\begin{array}{l}4.99 E-08 \\
8.24 E-09\end{array}$ & $\begin{array}{l}\text { None } \\
\text { None }\end{array}$ & $\begin{array}{l}\text { None } \\
\text { None. }\end{array}$ & 0.00471 & $1.40 E+04$ & $\begin{array}{l}3.35 \mathrm{E}-07 \\
592 \mathrm{9}-07 \\
\end{array}$ & $\frac{3.06 \mathrm{E}-07}{541 \mathrm{~F}-07}$ & $\begin{array}{l}1.40 E+00 \\
3.00+00\end{array}$ & $\begin{array}{l}2.19 \mathrm{E}-07 \\
180 \mathrm{E}-07 \\
\end{array}$ & \\
\hline \begin{tabular}{|l} 
methyy isobutyl ketone \\
nickel
\end{tabular} & 0.0065 & $\begin{array}{l}1.09 \mathrm{E}+04 \\
1.32 \mathrm{E}+09\end{array}$ & $5.92 E-07$ & $8.24 \mathrm{E}-09$ & $\begin{array}{c}\text { None } \\
9.10 \mathrm{E}-01\end{array}$ & $\begin{array}{l}\text { None } \\
\text { None }\end{array}$ & $\frac{0.0065}{48.5}$ & \begin{tabular}{|l|}
$1.09 E \mathrm{E}+04$ \\
$1.32 \mathrm{E}+09$
\end{tabular} & $\begin{array}{l}5.92 \mathrm{E}-07 \\
3.67 \mathrm{E}-08\end{array}$ & $\begin{array}{l}5.416 \mathrm{E}-07 \\
.36-08\end{array}$ & $\frac{3.00+00}{1.40 \mathrm{E}-05}$ & $\frac{1.80 \mathrm{E}-07}{2.40 \mathrm{E}-03}$ & \\
\hline petroleum hydrocarbons as diesel & 142 & $780 \mathrm{E}+03$ & $182 E-02$ & 8 2.2E-09 $\longrightarrow$ & None & None & 142 & $780 \mathrm{E}+03$ & $82 \mathrm{E}-02$ & $166 \mathrm{E}-02$ & $290 \mathrm{E}-01$ & $572 \mathrm{E}-02$ & \\
\hline silver allpiatics) & 1.2 & $\begin{array}{l}1.00 \mathrm{E}+03 \\
1.32 \mathrm{E}+09 \\
\end{array}$ & $\begin{array}{l}1.0 \angle E-0 L \\
9.35 E-10\end{array}$ & $\begin{array}{l}0.24 \mathrm{E}-09 \\
.39 \mathrm{E}-10\end{array}$ & None & None & 1.234 & \begin{tabular}{|r|}
$1.00+03$ \\
\end{tabular} & $\begin{array}{l}9.02-0 L \\
9.35 E-10\end{array}$ & $\frac{1.00-0 L}{8.54 E-10}$ & $\begin{array}{l}\text {. } \\
\text { None }\end{array}$ & $\begin{array}{l}\text { S.ILE-UL } \\
\text { None }\end{array}$ & \\
\hline tetrachloroethylene (PCE) & 0.010 & $2.26 \mathrm{E}+03$ & $4.47 \mathrm{E}-06$ & $6.64 \mathrm{E}-07$ & $2.10 \mathrm{E}-02$ & $1.40 \mathrm{E}-08$ & 0.01008 & $2.26 \mathrm{E}+03$ & $4.47 \mathrm{E}-06$ & $4.08 \mathrm{E}-06$ & $1.00 \mathrm{E}-02$ & $4.08 \mathrm{E}-04$ & \\
\hline \begin{tabular}{|l|} 
toluene \\
trichlothane
\end{tabular} & 0.00081 & $4.75 \mathrm{E}+03$ & \begin{tabular}{|l|}
$1.71 \mathrm{E}-07$ \\
.9207
\end{tabular} & $2.54 E-08$ & None & None & 0.01008 & $4.75 \mathrm{E}+03$ & $2.12 \mathrm{E}-06$ & $1.94 \mathrm{E}-06$ & $8.60 \mathrm{E}-02$ & $2.25 \mathrm{E}-05$ & \\
\hline 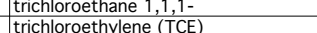 & 0.0007 & $\begin{array}{l}1.70 E+03 \\
2.35 E+03\end{array}$ & \begin{tabular}{|l|}
$3.84 E-07$ \\
$1.5 F-05$
\end{tabular} & $\begin{array}{l}8.24 \mathrm{E}-09 \\
2.31 \mathrm{E}-06\end{array}$ & $\begin{array}{c}\text { None } \\
7.00 E-03\end{array}$ & None & $\begin{array}{l}0.0007 \\
0.03651\end{array}$ & \begin{tabular}{|l|}
$1.70 E+03$ \\
$235 E+03$
\end{tabular} & $\begin{array}{l}3.84 \mathrm{E}-07 \\
1.55 \mathrm{~F}-05\end{array}$ & $\begin{array}{l}3.51 \mathrm{E}-07 \\
142 \mathrm{E}-05 \\
\end{array}$ & $6.30 \mathrm{E}-01$ & $5.57 \mathrm{E}-07$ & \\
\hline $\begin{array}{l}\text { thichioroethylene (ICE) } \\
\text { vanadium }\end{array}$ & 34.4 & $\begin{array}{l}2.35 \mathrm{E}+03 \\
1.32 \mathrm{E}+09 \\
\end{array}$ & \begin{tabular}{|l|}
$.53 E-05$ \\
$2.61 E-08$
\end{tabular} & $\begin{array}{l}\frac{2.311-06}{3.88 E-09} \\
\end{array}$ & $\frac{7.00 \mathrm{E}-03}{\text { None }}$ & $\begin{array}{l}1.62-08 \\
\text { None }\end{array}$ & $\frac{0.03651}{34.4}$ & \begin{tabular}{|l|}
$.35 E+03$ \\
$1.32 E+09$ \\
\end{tabular} & $\begin{array}{l}2.53 \mathrm{E}-05 \\
2.61 \mathrm{E}-08\end{array}$ & $\begin{array}{l}2.4 \angle \mathrm{E}-05 \\
2.38 \mathrm{E}-08\end{array}$ & $\begin{array}{l}1.70 \mathrm{E}-0 \mathrm{~L} \\
\text { None }\end{array}$ & $\begin{array}{l}8.34-04 \\
\text { None }\end{array}$ & \\
\hline xylene & 0.0021 & $6.63 \mathrm{E}+03$ & $3.15 \mathrm{E}-07$ & $4.69 \mathrm{E}-08$ & None & None & 0.01008 & $6.63 \mathrm{E}+03$ & $1.52 \mathrm{E}-06$ & $1.39 \mathrm{E}-06$ & $2.00 \mathrm{E}-01$ & $6.94 \mathrm{E}-06$ & \\
\hline zinc & 64.2 & $1.32 E+09$ & $4.86 \mathrm{E}-08$ & $7.23 \mathrm{E}-09$ & None & None & 64.2 & $1.32 \mathrm{E}+09$ & $4.86 \mathrm{E}-08$ & 4.44E-08 & None & None & \\
\hline & & & & & Risk $\Sigma=$ & $1.7 \mathrm{E}-07$ & & & & & Hazard $\Sigma=$ & $6.6 \mathrm{E}-02$ & \\
\hline
\end{tabular}


Attachment C (continued)

\begin{tabular}{|c|c|c|c|c|c|c|c|c|c|}
\hline & & & & & \multirow{2}{*}{\multicolumn{2}{|c|}{ DETERMINATION OFNONCARCINOGENIC HAZARD: }} & & & \\
\hline Ingestion & & FOR DETERMINATION OF EXCESS CANCER RIS & Adult & Child & & & Adult & Child & \\
\hline Residential Exposure & & Exposure frequency (EF; $d / y)$ & 350 & 350 & \multicolumn{2}{|c|}{ Exposure frequency $(E F ; d / y)$} & 350 & \multirow{4}{*}{\multicolumn{2}{|c|}{$\begin{array}{r}350 \\
6 \\
2,190 \\
15\end{array}$}} \\
\hline & & Exposure duration (ED; $y$ of residence) & 24 & & \multicolumn{2}{|c|}{ Exposure duration (ED; $y$ of residence) } & 24 & & \\
\hline & & Averaging time (AT; days in lifetime) & 25,550 & 25,550 & & 8,760 & & \\
\hline & & Body weight (BW; kg) & 70 & 15 & \multicolumn{2}{|c|}{\begin{tabular}{|l|} 
Averaging time (AT; days in age group) \\
Body weight (BW; kg)
\end{tabular}} & $\begin{array}{r}0,160 \\
70 \\
\end{array}$ & & \\
\hline & & Ingestion rate $(\mathrm{kg} / \mathrm{d})$ & 5.E-05 & 1.E-04 & \multirow{2}{*}{\multicolumn{2}{|c|}{\begin{tabular}{|l|l}
4 & Ingestion rate $(\mathrm{kg} / \mathrm{d})$ \\
7 & Exposure Factor $(\mathrm{d}-1)$ \\
\end{tabular}}} & 1.E-04 & \multirow{2}{*}{\multicolumn{2}{|c|}{$\begin{aligned} 1 . \mathrm{E}-04 \\
708 \mathrm{E}-6\end{aligned}$}} \\
\hline & & Exposure Factor $(\mathrm{d}-1)$ & & $7.83 \mathrm{E}-07$ & & & & & \\
\hline & & & & & & & & & \\
\hline & & & & & & & & & \\
\hline & & Contribution to & & & $95 \%$ UCL of & Contribution to & & & \\
\hline & Soil & CANCER RISK & Cancer slope & & measured soil & HAZARD & Reference & & \\
\hline Material present in soil at & concentration & EXPOSURE & factor--oral & Carcinogenic & concentration & EXPOSURE & oral dose & Hazard index & \\
\hline Area 514 & $(\mathrm{mg} / \mathrm{kg})$ & at $B 514(\mathrm{mg} / \mathrm{kg} \bullet \mathrm{d})$ & $\operatorname{Risk} /(\mathrm{mg} / \mathrm{kg} \bullet \mathrm{d})$ & Risk & $(\mathrm{mg} / \mathrm{kg})$ & $(\mathrm{mg} / \mathrm{kg} \bullet \mathrm{d})$ & $(\mathrm{mg} / \mathrm{kg} \bullet \mathrm{d})$ & (Exposure/Rfd) & \\
\hline Aroclor 1242 & 0.058 & $4.56 \mathrm{E}-08$ & $5.00 E+00$ & $2.28 \mathrm{E}-07$ & 0.058 & $4.12 \mathrm{E}-07$ & $2.00 \mathrm{E}-05$ & $2.06 \mathrm{E}-02$ & \\
\hline Aroclor 1254 & 0.019 & $1.52 \mathrm{E}-08$ & $5.00 \mathrm{E}+00$ & $7.58 \mathrm{E}-08$ & 0.019 & $1.37 \mathrm{E}-07$ & $2.00 \mathrm{E}-05$ & $6.86 \mathrm{E}-03$ & \\
\hline Aroclor 1260 & 0.049 & $3.84 \mathrm{E}-08$ & $5.00 \mathrm{E}+00$ & $1.92 \mathrm{E}-07$ & 0.049 & $3.47 \mathrm{E}-07$ & $2.00 \mathrm{E}-05$ & $1.74 \mathrm{E}-02$ & \\
\hline benzene & 0.00023 & $1.80 \mathrm{E}-10$ & $1.00 \mathrm{E}-01$ & $1.80 \mathrm{E}-11$ & 0.00023 & $1.63 \mathrm{E}-09$ & $4.00 \mathrm{E}-03$ & 4.07E-07 & \\
\hline beryllium & & & $4.30 \mathrm{E}+00$ & None & 0.36 & $2.55 \mathrm{E}-06$ & $2.00 \mathrm{E}-03$ & $1.27 \mathrm{E}-03$ & \\
\hline bis-2-ethylhexyl phthlate & 0.082 & $6.43 \mathrm{E}-08$ & $8.40 \mathrm{E}-03$ & $5.40 \mathrm{E}-10$ & 0.082 & $5.81 \mathrm{E}-07$ & $2.00 \mathrm{E}-02$ & $2.91 \mathrm{E}-05$ & \\
\hline bromomethane & 0.001 & $7.80 \mathrm{E}-10$ & None & None & 0.001 & $7.06 \mathrm{E}-09$ & $1.40 \mathrm{E}-03$ & $5.04 \mathrm{E}-06$ & \\
\hline carbon tetrachloride & 0.00015 & $1.17 \mathrm{E}-10$ & $1.50 \mathrm{E}-01$ & $1.76 \mathrm{E}-11$ & 0.00015 & $1.06 \mathrm{E}-09$ & $7.00 \mathrm{E}-04$ & $1.52 \mathrm{E}-06$ & \\
\hline chloroform & 0.00016 & $1.21 \mathrm{E}-10$ & $3.10 \mathrm{E}-02$ & $3.76 \mathrm{E}-12$ & 0.000155 & $1.10 \mathrm{E}-09$ & $1.00 \mathrm{E}-02$ & $1.10 \mathrm{E}-07$ & \\
\hline chloromethane & 0.00027 & $2.11 \mathrm{E}-10$ & $1.30 \mathrm{E}-02$ & $2.75 \mathrm{E}-12$ & 0.00027 & $1.91 \mathrm{E}-09$ & None & None & \\
\hline chromium (total) (used chromium III & 24.9 & $1.95 \mathrm{E}-05$ & None & None & 34.5 & $2.44 \mathrm{E}-04$ & $1.50 \mathrm{E}+00$ & $1.63 \mathrm{E}-04$ & \\
\hline chromium (hexavalent) & 0.325 & $2.54 \mathrm{E}-07$ & None & None & 0.325 & $2.30 \mathrm{E}-06$ & $3.00 \mathrm{E}-03$ & $7.67 \mathrm{E}-04$ & \\
\hline cobalt & 39.50 & $3.09 \mathrm{E}-05$ & None & None & 39.50 & $2.80 \mathrm{E}-04$ & $2.00 \mathrm{E}-02$ & $1.40 \mathrm{E}-02$ & \\
\hline copper & 27.5 & $2.15 \mathrm{E}-05$ & None & None & 27.5 & $1.95 \mathrm{E}-04$ & $4.00 \mathrm{E}-02$ & $4.87 \mathrm{E}-03$ & \\
\hline dibutyl phthlate & 0.088 & $6.85 \mathrm{E}-08$ & None & None & 0.088 & $6.20 \mathrm{E}-07$ & $1.00 \mathrm{E}-01$ & $6.20 \mathrm{E}-06$ & \\
\hline mercury & 0.11 & $8.59 \mathrm{E}-08$ & None & None & 0.1098 & $7.77 \mathrm{E}-07$ & $3.00 \mathrm{E}-03$ & $2.59 \mathrm{E}-04$ & \\
\hline methylene chloride & 0.005 & $4.11 \mathrm{E}-09$ & $1.40 \mathrm{E}-02$ & $5.76 \mathrm{E}-11$ & 0.005 & $3.72 \mathrm{E}-08$ & $6.00 \mathrm{E}-02$ & $6.20 \mathrm{E}-07$ & \\
\hline methyl ethyl ketone & 0.0047 & $3.69 \mathrm{E}-09$ & None & None & 0.00471 & $3.33 \mathrm{E}-08$ & $6.00 \mathrm{E}-01$ & $5.56 \mathrm{E}-08$ & \\
\hline methyl isobutyl ketone & 0.0065 & $5.05 \mathrm{E}-09$ & None & None & 0.0065 & $4.57 \mathrm{E}-08$ & $8.00 \mathrm{E}-02$ & $5.71 \mathrm{E}-07$ & \\
\hline nickel & & & None & None & 48.5 & $3.43 \mathrm{E}-04$ & $2.00 \mathrm{E}-02$ & $1.72 \mathrm{E}-02$ & \\
\hline petroleum hydrocarbons as diesel & & & & & & & & & \\
\hline (c9-c18 aliphatics) & 142 & $1.11 \mathrm{E}-04$ & None & None & 142 & $1.00 \mathrm{E}-03$ & 1.00E-01 & $1.00 \mathrm{E}-02$ & \\
\hline silver & 1.2 & $9.66 \mathrm{E}-07$ & None & None & 1.234 & $8.73 \mathrm{E}-06$ & $5.00 \mathrm{E}-03$ & $1.75 \mathrm{E}-03$ & \\
\hline tetrachloroethylene (PCE) & 0.010 & $7.89 \mathrm{E}-09$ & $5.40 \mathrm{E}-01$ & $4.26 \mathrm{E}-09$ & 0.01008 & $7.13 \mathrm{E}-08$ & $1.00 \mathrm{E}-02$ & $7.13 \mathrm{E}-06$ & \\
\hline toluene & 0.00081 & $6.34 \mathrm{E}-10$ & None & None & 0.01008 & $7.13 \mathrm{E}-08$ & $2.00 \mathrm{E}-01$ & $3.57 \mathrm{E}-07$ & \\
\hline trichloroethane $1,1,1-$ & 0.0007 & $1.80 \mathrm{E}-10$ & None & None & 0.0007 & $4.62 \mathrm{E}-09$ & $2.00 \mathrm{E}-01$ & $2.31 \mathrm{E}-08$ & \\
\hline trichloroethylene (TCE) & 0.037 & $2.86 \mathrm{E}-08$ & $1.30 \mathrm{E}-02$ & $3.72 \mathrm{E}-10$ & 0.03651 & $2.58 \mathrm{E}-07$ & $3.00 \mathrm{E}-04$ & $8.61 \mathrm{E}-04$ & \\
\hline vanadium & 34.4 & $2.69 \mathrm{E}-05$ & None & None & 34.4 & $2.43 \mathrm{E}-04$ & $7.00 \mathrm{E}-03$ & $3.48 \mathrm{E}-02$ & \\
\hline xylene & 0.0021 & $1.64 \mathrm{E}-09$ & None & None & 0.01008 & $7.13 \mathrm{E}-08$ & $2.00 \mathrm{E}-01$ & $3.57 \mathrm{E}-07$ & \\
\hline zinc & 64.2 & $5.03 \mathrm{E}-05$ & None & None & 64.2 & $4.54 \mathrm{E}-04$ & $3.00 \mathrm{E}-01$ & $1.51 \mathrm{E}-03$ & \\
\hline & & & Risk $=$ & $5.0 \mathrm{E}-07$ & & & Hazard $=$ & $1.3 \mathrm{E}-01$ & \\
\hline
\end{tabular}


Attachment C (continued)

\begin{tabular}{|c|c|c|c|c|c|c|c|c|c|c|c|}
\hline Dermal Absorption & & FOR DETERMINATION OF EXCES & ANCER RISK: & Adult & Child & FOR DETERMINATION OF NONCARCINOC & GENIC HAZAF & Adult & Child & & \\
\hline Residential Exposure & & $\mid$ Exposure frequency $(E F ; d / y) \mid$ & & 350 & 350 & Exposure frequency $(E F ; d / y)$ & & 350 & 350 & & \\
\hline & & Exposure duration (ED; $y$ in age & & 24.0 & & Exposure duration (ED; $y$ in age group) & & 24.0 & 6 & & \\
\hline & & Averaging time (AT; days in life & & 25,550 & 25,550 & Averaging time (AT; days in age group) & & 8,760 & 2,190 & & \\
\hline & & Body weight $(\mathrm{BW} ; \mathrm{kg})$ & & 70 & & Body weight $(\mathrm{BW} ; \mathrm{kg})$ & & $\frac{8,70}{70}$ & $\frac{15}{15}$ & & \\
\hline & & Soil adherence factor $(\mathrm{mg} / \mathrm{cm} 2$ & & 0.20 & 0.20 & Soil adherence factor $(\mathrm{mg} / \mathrm{cm} 2)$ & & 0.20 & 0.20 & & \\
\hline & & Skin surface area exposure rate & Aadult; cm2/d) & 5,800 & 2806 & Skin surface area exposure rate (SSAadu & lit; cm2/d) & 5,800 & & & \\
\hline & & Unit conversion $(10-6 \mathrm{~kg} / \mathrm{mg})$ & & $\frac{1.0-06}{1 . E-06}$ & $1 . \mathrm{E}-06$ & Unit conversion $(10-6 \mathrm{~kg} / \mathrm{mg})$ & & $\frac{1,006}{1 . E-06}$ & & & \\
\hline & & Exposure Factor $(\mathrm{d}-1)=$ & & & $8.52 \mathrm{E}-06$ & Exposure Factor $(d-1)=$ & & & $5.18 \mathrm{E}-05$ & & \\
\hline & & & & & & & & & & & \\
\hline & & & Contribution to & & & $95 \%$ UCL of & & Contribution to & & & \\
\hline & Soil & & CANCER RISK & Cancer slope & & measured soil & & HAZARD & Reference & & \\
\hline Material present in soil at & concentration & Absorption & EXPOSURE & factor--dermal & Carcinogenic & concentration & Absorption & EXPOSURE & dermal dose & Hazard index & \\
\hline Area 514 & $(\mathrm{mg} / \mathrm{kg})$ & fraction & at B514 $(\mathrm{mg} / \mathrm{kg} \bullet \mathrm{d})$ & $\operatorname{Risk} /(\mathrm{mg} / \mathrm{kg} \bullet \mathrm{d})$ & Risk & $(\mathrm{mg} / \mathrm{kg})$ & fraction & $(\mathrm{mg} / \mathrm{kg} \bullet \mathrm{d})$ & $(\mathrm{mg} / \mathrm{kg} \bullet \mathrm{d})$ & Exposure/Rfd & \\
\hline Aroclor 1242 & 0.058 & $1.40 \mathrm{E}-01$ & $6.95 \mathrm{E}-08$ & $5.00 \mathrm{E}+00$ & $3.48 \mathrm{E}-07$ & 0.058 & $1.40 \mathrm{E}-01$ & $4.22 \mathrm{E}-07$ & $2.00 \mathrm{E}-05$ & $2.11 \mathrm{E}-02$ & \\
\hline Aroclor 1254 & 0.019 & $1.40 \mathrm{E}-01$ & $2.31 \mathrm{E}-08$ & $5.00 E+00$ & $1.16 \mathrm{E}-07$ & 0.019 & $1.40 \mathrm{E}-01$ & $1.40 \mathrm{E}-07$ & $2.00 \mathrm{E}-05$ & $7.02 \mathrm{E}-03$ & \\
\hline Aroclor 1260 & 0.049 & $1.40 \mathrm{E}-01$ & $5.86 \mathrm{E}-08$ & $5.00 E+00$ & $2.93 \mathrm{E}-07$ & 0.049 & $1.40 \mathrm{E}-01$ & $3.56 \mathrm{E}-07$ & $2.00 \mathrm{E}-05$ & $1.78 \mathrm{E}-02$ & \\
\hline benzene & 0.00023 & $1.00 \mathrm{E}-02$ & $1.96 \mathrm{E}-11$ & $1.00 \mathrm{E}-01$ & $1.96 \mathrm{E}-12$ & 0.00023 & $1.00 \mathrm{E}-02$ & $1.19 \mathrm{E}-10$ & $4.00 \mathrm{E}-03$ & $2.98 \mathrm{E}-08$ & \\
\hline beryllium & & $1.00 \mathrm{E}-03$ & & $4.30 \mathrm{E}+00$ & $0.00 E+00$ & 0.36 & $1.00 \mathrm{E}-03$ & $1.86 \mathrm{E}-08$ & $2.00 \mathrm{E}-03$ & $9.32 \mathrm{E}-06$ & \\
\hline bis-2-ethylhexyl phthlate & 0.082 & $1.00 \mathrm{E}-02$ & $7.00 \mathrm{E}-09$ & $3.00 \mathrm{E}-03$ & $2.10 \mathrm{E}-11$ & 0.082 & $1.00 \mathrm{E}-02$ & $4.25 \mathrm{E}-08$ & $2.00 \mathrm{E}-02$ & $2.12 \mathrm{E}-06$ & \\
\hline $\begin{array}{l}\text { bromomethane } \\
\text { araron tetrachloride }\end{array}$ & 0.001 & $1.00 \mathrm{E}-02$ & $8.50 \mathrm{E}-11$ & None & None & 0.001 & $1.00 \mathrm{E}-02$ & $5.16 \mathrm{E}-10$ & $1.40 \mathrm{E}-03$ & $3.69 \mathrm{E}-07$ & \\
\hline $\begin{array}{l}\text { carbon tetrachloride } \\
\text { chloroform }\end{array}$ & $\begin{array}{l}0.00015 \\
0.00016\end{array}$ & $\frac{1.00 \mathrm{E}-02}{1.00 \mathrm{E}-02}$ & $\frac{1.28 \mathrm{E}-11}{1.32 \mathrm{E}-11}$ & $\frac{1.50 \mathrm{E}-01}{3.0 \mathrm{E}-02}$ & \begin{tabular}{|l|}
$1.92 \mathrm{E}-12$ \\
$4.10 \mathrm{E}-13$ \\
\end{tabular} & $\begin{array}{c}0.00015 \\
0.000155\end{array}$ & \begin{tabular}{|l|}
$1.00 E-02$ \\
$1.00 \mathrm{E}-02$
\end{tabular} & $\frac{7.76 \mathrm{E}-11}{8.02 \mathrm{E}-11}$ & $\begin{array}{l}7.00 \mathrm{E}-04 \\
1.00 \mathrm{E}-02\end{array}$ & $\begin{array}{l}1.11 \mathrm{E}-07 \\
8.02 \mathrm{E}-09\end{array}$ & \\
\hline chloromethane & $\begin{array}{l}0.00016 \\
0.00027\end{array}$ & $\begin{array}{l}1.00 \mathrm{E}-\mathrm{Cl} \\
1.00 \mathrm{-02}\end{array}$ & $\frac{1.32 \mathrm{E}-11}{2.30 \mathrm{E}-11}$ & $\begin{array}{l}\frac{3.10 \mathrm{~L}-0 \mathrm{~L}}{1.30 \mathrm{E}-02} \\
\end{array}$ & \begin{tabular}{|l|}
$2.90 E-13$ \\
$2.99 E-13$ \\
\end{tabular} & 0.00027 & \begin{tabular}{|l|}
$.00 E-02$ \\
$1.00 E-02$ \\
\end{tabular} & $\frac{0.0 \angle E-11}{1.40 E-10}$ & None & $\begin{array}{l}0.0<\mathrm{L}-\mathrm{Cy} \\
\text { None }\end{array}$ & \\
\hline chromium (total) (used chrom & $\frac{0.000<1}{24.9}$ & $1.00 \mathrm{E}-03$ & $\frac{2.50 \mathrm{E}-11}{2.12 \mathrm{E}-07}$ & None & None & 34.5 & \begin{tabular}{|l|l|}
$.00 E-02$ \\
$1.00 E-03$
\end{tabular} & $1.49 \mathrm{E}-06$ & $1.50 \mathrm{E}+00$ & $\begin{array}{l}\text { None } \\
1.19 E-06\end{array}$ & \\
\hline chromium (hexavalent) & 0.325 & $\begin{array}{l}1.00 \mathrm{E}-0 \mathrm{~s} \\
.00-03\end{array}$ & $\begin{array}{l}2.12 \mathrm{E}-01 \\
2.77 \mathrm{E}-09\end{array}$ & None & None & 0.325 & \begin{tabular}{|l|l|}
$1.00 E-05$ \\
\end{tabular} & $1.68 \mathrm{E}-08$ & $3.00 \mathrm{E}-03$ & $\begin{array}{l}1.19 \mathrm{E}-00 \\
5.61 \mathrm{E}-06\end{array}$ & \\
\hline cobalt & 39.50 & $\begin{array}{l}1.00 \mathrm{E}-0 \mathrm{~J} \\
1.00-03\end{array}$ & $3.37 \mathrm{E}-07$ & None & None & 39.50 & \begin{tabular}{|l|l|} 
& $1.00 \mathrm{E}-03$ \\
\end{tabular} & $2.04 \mathrm{E}-06$ & $\frac{0.00 \mathrm{E}-02}{2.00 \mathrm{C}}$ & $\begin{array}{l}1.015-00 \\
1.02 E-04\end{array}$ & \\
\hline $\begin{array}{l}\text { coudal } \\
\text { copper }\end{array}$ & $\frac{3.100}{27.5}$ & $\begin{array}{l}1.00 \mathrm{E}-0 \mathrm{~J} \\
1.00-03\end{array}$ & $2.34 \mathrm{E}-07$ & None & None & 27.5 & \begin{tabular}{|l|l|} 
& $1.00 \mathrm{E}-03$ \\
\end{tabular} & $1.42 \mathrm{E}-06$ & $4.00 \mathrm{E}-02$ & $3.56 \mathrm{E}-05$ & \\
\hline dibutyl phthlate & 0.088 & $1.00 \mathrm{E}-02$ & $7.46 \mathrm{E}-09$ & None & None & 0.088 & \begin{tabular}{|l|}
$1.00 \mathrm{E}-02$ \\
\end{tabular} & $4.53 \mathrm{E}-08$ & $\begin{array}{l}1.00 \mathrm{E}-\mathrm{C}-01 \\
1.00 \mathrm{~s}\end{array}$ & $4.53 \mathrm{E}-07$ & \\
\hline mercury & 0.11 & $1.00 \mathrm{E}-03$ & $9.36 \mathrm{E}-10$ & None & None & 0.1098 & $1.00 \mathrm{E}-03$ & $5.68 \mathrm{E}-09$ & $3.00 \mathrm{E}-03$ & $1.89 \mathrm{E}-06$ & \\
\hline methylene chloride & 0.005 & $1.00 \mathrm{E}-02$ & $4.48 \mathrm{E}-10$ & $1.40 \mathrm{E}-02$ & $6.27 E-12$ & 0.005 & $1.00 \mathrm{E}-02$ & $2.72 \mathrm{E}-09$ & $6.00 \mathrm{E}-02$ & $4.53 \mathrm{E}-08$ & \\
\hline methyl ethyl ketone & 0.0047 & $1.00 \mathrm{E}-02$ & $4.01 \mathrm{E}-10$ & None & None & 0.00471 & $1.00 \mathrm{E}-02$ & $2.44 \mathrm{E}-09$ & $6.00 \mathrm{E}-01$ & $4.06 \mathrm{E}-09$ & \\
\hline methyl isobutyl ketone & 0.0065 & $1.00 \mathrm{E}-02$ & $5.50 \mathrm{E}-10$ & None & None & 0.0065 & $1.00 \mathrm{E}-02$ & $3.34 \mathrm{E}-09$ & $8.00 \mathrm{E}-02$ & $4.17 \mathrm{E}-08$ & \\
\hline nickel & & $1.00 \mathrm{E}-03$ & & None & None & 48.5 & $1.00 \mathrm{E}-03$ & $2.51 \mathrm{E}-06$ & $2.00 \mathrm{E}-02$ & $1.26 \mathrm{E}-04$ & \\
\hline petroleum hydrocarbons as & 142 & 1 OOE- 02 & 127105 & Nop & None & 142 & 1.00200 & 739505 & 100501 & 73050 & \\
\hline \begin{tabular}{|l} 
diesel (c9-c18 aliphatics) \\
silver
\end{tabular} & $\frac{142}{1.2}$ & $\begin{array}{l}1.00 \mathrm{E}-02 \\
.00 \mathrm{E}-03\end{array}$ & $\begin{array}{l}1.21 \mathrm{E}-05 \\
.05 \mathrm{E}-08\end{array}$ & $\begin{array}{l}\text { None } \\
\text { None }\end{array}$ & $\begin{array}{l}\text { None } \\
\text { None }\end{array}$ & $\begin{array}{c}142 \\
1.234\end{array}$ & \begin{tabular}{|l|}
$.00 \mathrm{E}-02$ \\
$1.00 \mathrm{E}-03$
\end{tabular} & $\begin{array}{l}7.34 \mathrm{E}-05 \\
6.39 \mathrm{E}-08\end{array}$ & $\begin{array}{l}1.00 \mathrm{E}-01 \\
5.00 \mathrm{E}-03\end{array}$ & $\begin{array}{l}7.34 \mathrm{E}-04 \\
1.28 \mathrm{E}-05\end{array}$ & \\
\hline tetrachloroethylene (PCE) & 0.010 & $\begin{array}{l}1.000-00 \\
1.00-02\end{array}$ & $\frac{1.056-20}{8.59-10}$ & $5.40 \mathrm{E}-01$ & $4.64 \mathrm{E}-10$ & 0.01008 & \begin{tabular}{|l|l|}
$1.00 \mathrm{E}-02$ \\
\end{tabular} & $5.22 \mathrm{E}-09$ & $\begin{array}{l}.00 \mathrm{E}-00 \\
1.00 \mathrm{0}\end{array}$ & $5.22 \mathrm{E}-07$ & \\
\hline toluene & 0.00081 & 1.00 & $6.90 \mathrm{E}-11$ & None & None & 0.01008 & $1.00 \mathrm{E}-02$ & $5.22 \mathrm{E}-09$ & $2.00 \mathrm{E}-01$ & $2.61 \mathrm{E}-08$ & \\
\hline trichloroethane $1,1,1-$ & 0.0007 & $1.00 \mathrm{E}$ & $5.57 \mathrm{E}-11$ & None & None & 0.0007 & $1.00 \mathrm{E}-02$ & $3.38 \mathrm{E}-10$ & $2.00 \mathrm{E}-01$ & $1.69 \mathrm{E}-09$ & \\
\hline trichloroethylene (TCE) & 0.037 & $1.00 \mathrm{E}$ & 3.11 & $1.30 \mathrm{E}-02$ & $4.05 \mathrm{E}-11$ & 0.03651 & $1.00 \mathrm{E}-02$ & $1.89 \mathrm{E}-08$ & $3.00 \mathrm{E}-04$ & $6.30 \mathrm{E}-05$ & \\
\hline vanadium & 34.4 & $1.00 \mathrm{E}-03$ & 2.93 & None & None & 34.4 & $1.00 \mathrm{E}-03$ & $1.78 \mathrm{E}-06$ & $7.00 \mathrm{E}-03$ & $2.54 \mathrm{E}-04$ & \\
\hline xylene & 0.0021 & $1.00 \mathrm{E}-02$ & $1.78 \mathrm{E}-10$ & None & None & 0.01008 & $1.00 \mathrm{E}-02$ & $5.22 \mathrm{E}-09$ & $2.00 \mathrm{E}-01$ & $2.61 \mathrm{E}-08$ & \\
\hline zinc & 64.2 & $1.00 \mathrm{E}-03$ & 5.47E-07 & None & None & 64.2 & $1.00 \mathrm{E}-03$ & $3.32 \mathrm{E}-06$ & $3.00 \mathrm{E}-01$ & $1.11 \mathrm{E}-05$ & \\
\hline & & & & Risk $=$ & $7.6 \mathrm{E}-07$ & & & & Hazard Index & $4.7 \mathrm{E}-02$ & \\
\hline & & & & & & & & & & & \\
\hline
\end{tabular}

